\title{
Eruptive process, effects and deposits of the 1996 and the ancient basaltic phreatomagmatic eruptions in Karymskoye lake, Kamchatka, Russia
}

\author{
A.Belousov and M.Belousova

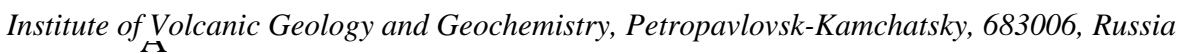

\begin{abstract}
On 2-3 January 1996 an explosive eruption discharging $=10^{6} \mathrm{kgs}^{-1}$ of basaltic magma occurred in Karymskoye lake at an initial water depth of $\sim 50 \mathrm{~m}$. Characteristics of the deposits together with analyses of a videotape of several explosions have allowed us to model the eruptive events. Initial vent-clearing phreatic explosions ejected blocks of country rocks (up to $3 \mathrm{~m}$ diameter) to distances of up to $1.3 \mathrm{~km}$. Then followed 10- $20 \mathrm{~h}$ of phreatomagmatic Surtseyan activity (100-200 outbursts of water-gas-pyroclastic mixtures to heights of up to $1 \mathrm{~km}$, with initial velocities of $110 \mathrm{~m} \mathrm{~s}^{-1}$. The eruption slugs collapsed back into the lake and produced base surges (runout up to $1.3 \mathrm{~km}$; average velocity $12.5 \mathrm{~m} \mathrm{~s}^{-1}$ ). The convective eruption plume rose to a height of $3 \mathrm{~km}$ and deposited a thin distal fall deposit. The eruption ended with the ejection of scoria-crust bombs (specific basaltic bombs with dense core and scoriaceous crust).

Pyroclasts of the eruption are mostly poorly to moderately vesicular juvenile basaltic particles shaped by a combination of magmatic vesiculation and magma-water interaction. Ninety-five percent of the products $\left(0.047 \mathrm{~km}^{3}\right)$ formed an underwater tuff ring composed of parallel layers of moderately to poorly sorted lapilli ash and ash lapilli (Md - 3.9 to $0.6 \mathrm{phi}$; sorting 1.5-3.2 phi), each 10-60 cm thick. They were deposited by water-rich base surges that originated from Surtseyan type eruption bursts. The most widespread hazards of the eruption were tsunamis and lahars. At distances $<1.3 \mathrm{~km}$ from the crater, base surges and ballistic clasts were very destructive.

Eruptive activity in the lake before 1996 included two eruptions at c. $4800{ }^{14} \mathrm{C}$ yr BP. The first left deposits similar to those of the 1996 eruption and thus is interpreted as a Surtseyan eruption that occurred at the same water depth as in 1996. The second of the $4800^{14} \mathrm{C}$ yr BP eruptions deposited extensive cross-laminated base-surge deposits and is interpreted to have occurred in very shallow water.
\end{abstract}

\section{INTRODUCTTON}

The dynamics of eruptions are governed by many factors, the most important of which are properties and flux rate of magma, geometry of the conduit and vent, and environment in which, magma erupts (Fisher \& Schmincke, 1984; Francis, 1993). With respect to the last factor, there is much geological evidence, supported by direct observations of eruptions, that the presence of water in a place where an eruption occurs notably modifies the style of eruptive activity (e.g. Lorenz, 1973; Houghton \& Schmincke, 1986). When magma erupts into a 'wet' environment, fragmentation can occur not only as a result of expansion of magmatic volatiles, but also by energetic interaction between magma and external water (e.g. Houghton \& Wilson, 1989). This complicated process is modelled as analogous to fuel-coolant interaction (Kokelaar, 1983; Sheridan \& Wohletz. 1983; Wohletz, 1983, 1986; Wohletz \& McQueen, 1984; Zimanowski, 1998). Such eruptions are termed phreatomagmatic or hydrovolcanic.

As a result of the existence of an additional mechanism of fragmentation, subaerial phreatomagmatic eruptions (in which magma contacts ground water) are always more violent, and their magma is effectively more fragmented (pyroclasts are finer grained), than if the same magma was erupted in a dry environment (Walker \& Croasdale,1972; Heiken \& Wohletz, 1986). Processes of subaqueous explosive eruptions are more complicated. Violence of the explosions declines with increasing water depth because elevation of ambient pressure quickly suppresses explosive processes. Thus 
deep-water eruptions are relatively quiet and frequently purely effusive (e.g. Fisher \& Schmincke, 1984). An additional factor contributing to low explosivity of subaqueous eruptions, in comparison with subaerial phrcatomagmatic events, could be excess water. It was demonstrated by experiments with mixtures of water and silicate melts (Wohletz \& McQueen, 19S4) that the strongest explosions occur at intermediate water/melt ratios ( 0.3). Both higher and lower ratios lead to less violent explosions.

Shallow-water explosive eruptions (depth usually $<100 \mathrm{~m}$ ) are akin lo subaerial phreatomagmatic ones, but the ejection of pyroclasts through a layer of water adds many unique features to the eruptive and depositional processes. Shallow-water (especially sublacustrine) eruptions have been only poorly studied because of the rarity of direct observations. Most published observations of shallow-water explosions were made by Thorarinsson (1964) during the eruption of Surtsey (Iceland) in 1963. Similar 'Surtseyan' activity was witnessed also during the eruptions of Capelinhos, Azores, in 1957 (Machado et al, 1962; Waters \& Fisher, 1971).

Questions arising from the scarcity of direct observations of shallow-water eruptions have not been fully addressed by investigations of their deposits. Deposits of shallow-water eruptions are rare because of their rapid reworking by water waves and/or as a result of deep burial under deposits of subsequent subaerial volcanic activity. Thus few such deposits have been studied, and their processes of formation are the subject of debate (Heiken, 1971; Kokelaar. 1983; Cas et al, 1989; Sohn \& Chough, 1992: White, 1996).

The aim of this paper is to document the 1996 sublacustrine eruption in Karymskoye lake and resulting deposits, as well as deposits of similar eruptions that occurred in the lake in the past. From these data we infer mechanisms of magma fragmentation, and of the deposition of resulting pyroclasts, which operate during shallow-water eruptions of basic magma.

\section{GEOGRAPHICAL AND GEOLOGICAL SETTING}

Kamchatka Peninsula makes up the northern part of the Kurile-Kamchatka volcanic arc. Volcanism of the arc results from westward subduction of the Pacific plate under the Eurasian plate. About 30 active volcanoes of Kamchatka are aligned along the eastern shore of the peninsula. Together with a number of extinct volcanoes and calderas, they form the Eastern Volcanic Belt of Kamchatka (Fedotov, 1991).
Karymskoye intracaldera lake is located in an uninhabited region of the Eastern Volcanic Belt, $125 \mathrm{~km}$ north-east of the town Petropavlovsk-Kamchatsky (Figs $1 \& 2$ ). The lake, $4 \mathrm{~km}$ across with a maximum depth of $70 \mathrm{~m}$, contains $\sim 0.5 \mathrm{~km}^{3}$ of fresh water. The surface of the lake normally has an altitude of $624 \mathrm{~m}$ above sea-level (a.s.l.). From November to June the lake is covered by ice (up to $1 \mathrm{~m}$ thick) and snow (up to several metres thick). The steep shores of the lake are heavily vegetated by alder bushes with rare cedar bushes and birch trees. Before the eruption there were no well-developed beaches around the lake. The lake is fed by several streams and hot springs. In the north, the lake is drained by the Karymskaya river. The first and only pre-1996 depth sketch of the lake (Ya. D. Muravyev, personal communication) displays a simple bowl-like morphology of the bottom, complicated in the northern part of the lake by a broad shoal.

Around the lake there are several late Pleistocene-Holocene stratovolcanoes, of basalt to rhyodacite composition (Ivanov, 1970). Eruptions of rhyolites in the region have been widespread, connected mostly with formation of calderas. Karymskoye lake fills one of them-the Akademiya Nauk caldera, which is enclosed in an older, larger caldera. Akademiya Nauk caldera is bounded on all sides by a pronounced escarpment $50-150 \mathrm{~m}$ high. The ealdera was formed in late Pleistocene time; the fission-track age is $28-48 \mathrm{ka}$ (Masurenkov, 1980) and younger eruptions inside the caldera were not known until recently (Belousov et al., 1997). Modern volcanic activity of the region is connected mostly with Karymsky stratovolcano, which is situated $6 \mathrm{~km}$ to the north inside its own Karymsky caldera, $7800{ }^{14} \mathrm{C}$ yr old (Braitseva \& Melekestsev, 1990). This volcano erupts andesite and dacite and is one of the most active volcanoes in Kamchatka. In historic time (since 1771) more than 20 prolonged eruptions are known (Gushchenko, 1979). Before 1996 the volcano had been dormant since 1982 .

Akademiya Nauk caldera is crossed by a major north-north-east fault (Fig. 1) which is marked by a straight-lined drainage-system pattern (Belousov et al., 1997). Its most prominent expression is the straight deep canyon that was cut by the Karymskaya river into the rim of the caldera. Rare eruptions of basic magma have occurred along the fault in late Pleistocene-early Holocene time. They built several scoria cones and maars to the north of the caldera (Fig. 1) and also an underwater tuff ring inside the caldera, which was expressed as a shoal in the northern part of Karymskoye lake. The tuff ring was formed by two eruptions, which occurred closely one after another at $4800{ }^{\mathrm{I}} \mathrm{C}$ yr BP (Belousov et al, 1997). 


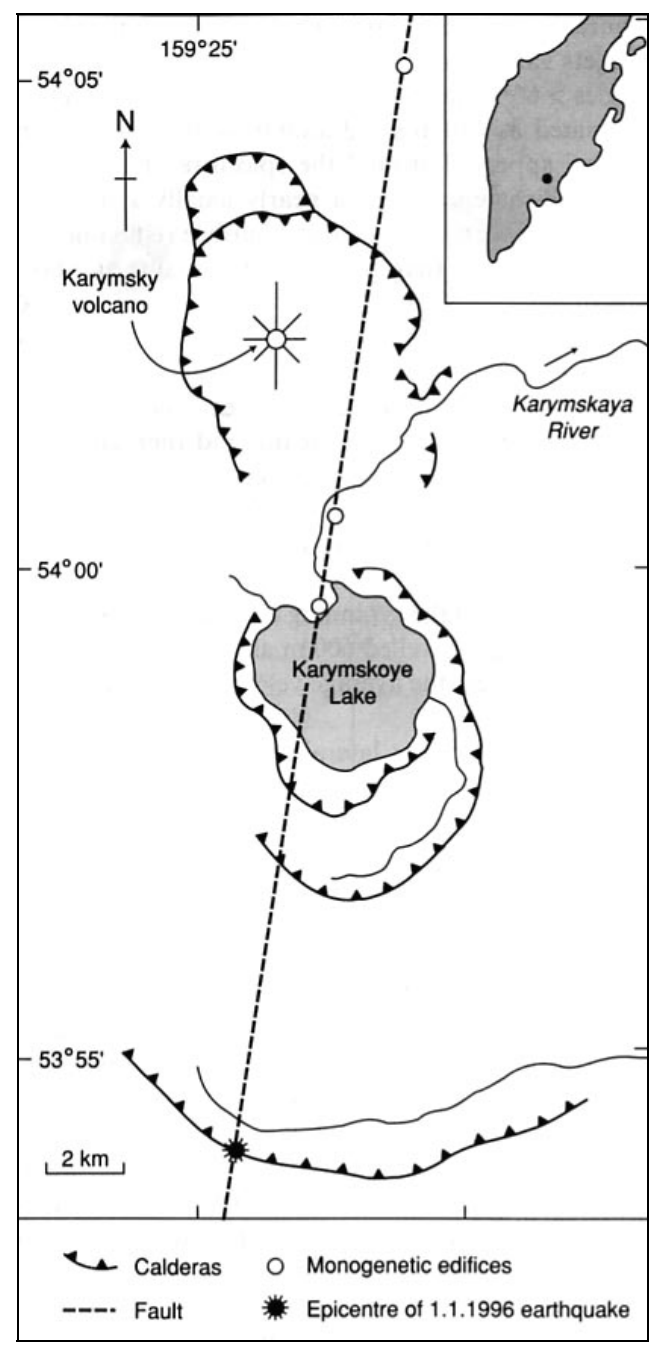

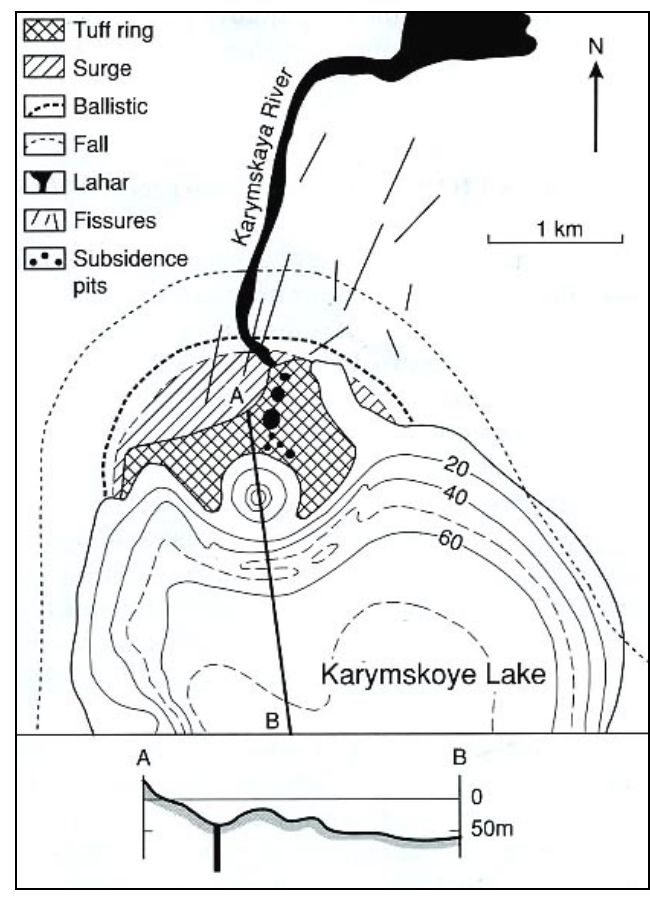

Fig.1.(a) Location of Karymskoye lake and Karymsky volcano, with inset showing their location on Kamchatka peninsula, (b) Sketch map of deposits of the 1996 eruption. Boundaries are drawn schematically. Deposits of tsunamis are not shown. Line A-B shows the position of bathymetric profile (below) across the 1996 tuff ring. Dashed isobaths are drawn for 55 in and $65 \mathrm{~m}$. A bump on the south slope of the 1996 tuff ring is probably a buried crater rim of the first eruption in the lake, dated at $4800^{14} \mathrm{C}$ yr BP.

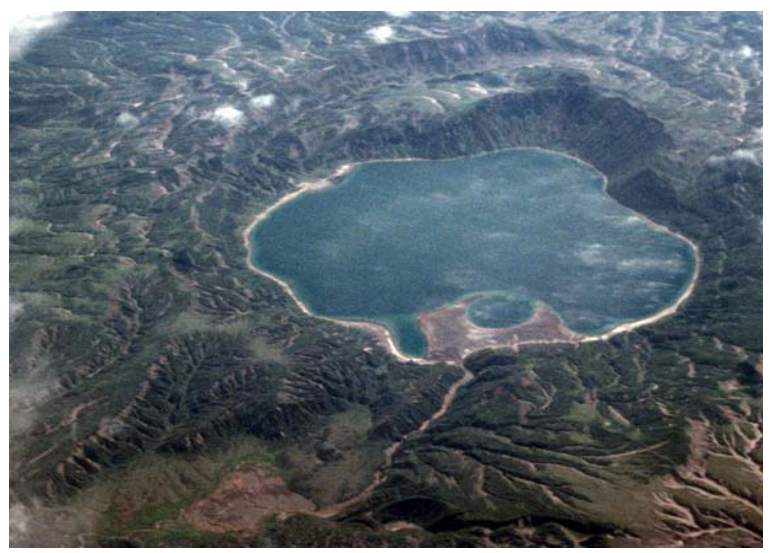

Fig. 2. Oblique view ofthe Karymskoye intracaldera lake and the 1996 tuff ring. View from the north-west. Karymsky stratovolcano is to the left, just beyond the frame. 
The 1996 eruption in the Karymskoye lake occurred at the underwater part of ihe north-north-east fault, at the same site as the $4800{ }^{14} \mathrm{C}$ yr BP eruptions.

\section{OBSERVATIONS OF THE 1996 ERUPTION}

After a strong earthquake on 1 January 1996 at $21.57 \mathrm{~h}$ local time (LT), there was an intense seismic swarm. Two explosive eruptions subsequently began, one after another, from two different and widely separated sources: one from the central vent of Karymsky stratovolcano and one from Karymskoye lake (Fcdotov, 1998; Muravyev el al., 1998). Reports from pilots of commercial flights led to the conclusion that Karymsky stratovolcano began to erupt first, apparently early in the morning on 2 January. During the first day of the eruption, Karymsky stratovolcano emitted a steady ash piume, which drifted south-east at $200-500 \mathrm{~m}$ above the summit crater (1700-2000 m a.s.l.).

The brief and violent eruption in Karymskoye lake started several hours after the beginning of the eruption of Karymsky stratovolcano, at approximately $13.00 \mathrm{~h} \mathrm{LT}$. The only observation of the eruptive processes in the lake was made during a helicopter overflight at 15.20-16.20 h LT (Muravyev el al., 1998). By the lime of the overflight, the ice cover of the lake had melted, and an eruption of Surtseyan type was in progress from a vent $400 \mathrm{~m}$ off the northern shore. Initial water depth at the vent site was $\sim 40-50 \mathrm{~m}$.

Underwater explosions occurred every 4-12 min; in total about six explosions were observed with an average interval of 6 min. Between the explosions, water of the lake at the site of the eruption was vigorously splashing, bubbling and steaming. The explosions had different magnitudes. Analysis of videotape of the strongest explosion, recorded by $\mathrm{V}$. Bahtiarov during the overflight, shows the following sequence of events (Fig. 3a).

1 The explosion initially produced a rapidly rising, dark grey, smooth-surfaced bulbous mass of expanding gas and pyroclasts, probably maintained by surface tension within a shell of water. Within several seconds the shell expanded up to $450 \mathrm{~m}$ high. The ejection angle of the material (between the lake surface and the outer margin of the expanding bulb) was about $60^{\circ}$.

2 Suddenly the shell became unstable and was pierced by multiple jets of a black mixture of pyroclasts with steam and water, of the type named 'cock's tail jets' by
Thorarinsson el al. (1964). Although ejection angles of the jets varied from $40^{\circ}$ to $90^{\circ}$, the strongest jets had angles $>60^{\circ}$. Maximum initial velocity of the jets is estimated as $110 \mathrm{~ms}^{-1}$. Simultaneously, a light grey 'collar' appeared around the epicentre of the explosion, which represented a nearly axially symmetric, bore-like elevation of the water surface (tsunami?) up to $130 \mathrm{~m}$ high, that propagated radially at about 40-20 $\mathrm{ms}^{-1}$.

3 Within $\sim 15 \mathrm{~s}$ from the beginning of the explosion and $<7 \mathrm{~s}$ after piercing the shell, the jets reached their maximum height of about $1 \mathrm{~km}$, became white as a result of condensation of steam, and then collapsed back toward the lake to produce a ground-hugging base surge that moved radially from the stem of the eruptive column with a maximum velocity of about $20 \mathrm{~m} \mathrm{~s}^{-1}$ (Fig. 3b).

4 Within $48 \mathrm{~s}$ of the beginning of base-surge propagation, the surge travelled $600 \mathrm{~m}$ along the lake surface and decelerated; the average velocity of the surge was $\sim 12.5 \mathrm{~ms}^{-1}$.

5 At the end of its lateral propagation the surge strongly expanded, apparently lost most of its pyroclastic load, became lighter than the surrounding air and began to lift buoyantly.

6 Soon the surge cloud rose from the ground and ascended convectively upward.

Other observed explosions were weaker than that described above. Most of them produced a single, vertical, column-like outburst of black gas-water pyroclastic mixtures $\sim 100-150 \mathrm{~m}$ high (the type named 'cypressoid jets' by Thorarinsson el al., 1964). The columns collapsed back into the lake, producing only subtle base surges. Large concentric water waves (tsunamis) with wavelengths of $\sim 100 \mathrm{~m}$ were seen on the surface of the lake around the site of the eruption. Above the sites of explosions, white, pyroclast-depleted eruptive clouds convected to an altitude of $\sim 3 \mathrm{~km}$ and then slowly drifted downwind to the south-east.

Tsunamis, generated by underwater explosions, periodically forced water from the lake into the canyon of Karymskaya river, forming pulsing lahars with a maximum discharge of $500 \mathrm{~m}^{3} \mathrm{~s}^{-1}$ (Muravyev et al., 1998). Four kilometres downstream from the headwaters, where the river emerges from its first deep canyon, a shallow temporary lake was formed because the next narrow canyon of the river was incapable of handling all of the lahar.

By the time of the next overflight, at $11.00 \mathrm{~h} \mathrm{LT}$ on 3 January, the eruption in Karymskoye lake had ceased. The precise time of the cessation is unknown because 

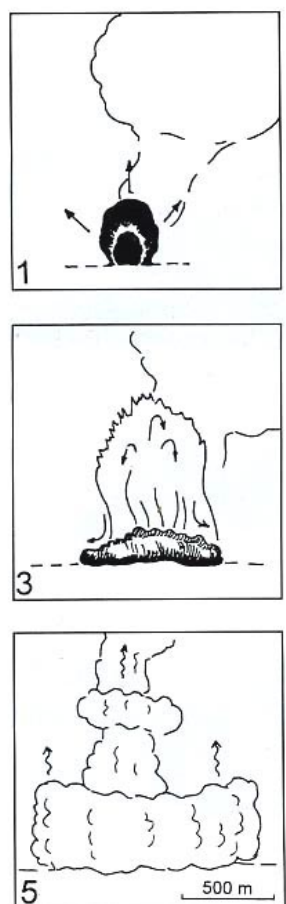
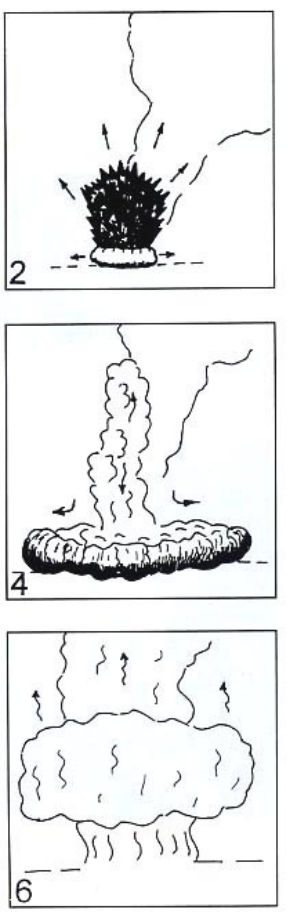

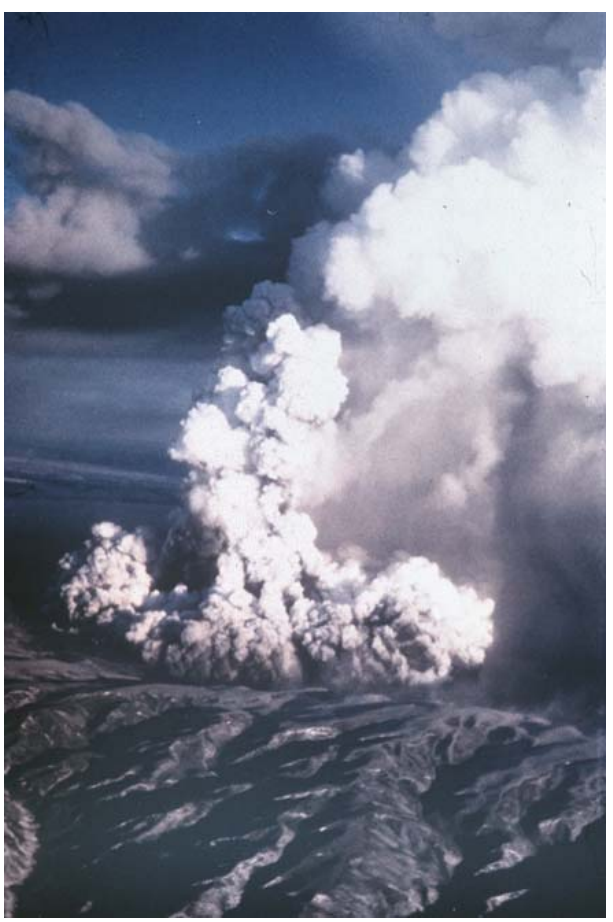

(b)

Fig. 3. Sublacustrine volcanic explosion m Karymskoye lake on 2 January 1996 al 15.42 h LT. View from the north-west. (a)Development of the explosion. Sketches drawn from the videotape. 1, Rapidly rising bulbous mass of black expanding gas and pyroclasts within a shell of water (inner contour). Within $3 \mathrm{~s}$ the shell has expanded to $450 \mathrm{~m}$ high (outer contour). White contour above is an ascending cloud from previous explosion. 2, The shell is pierced by multiple jets of a black mixture of pyroclasts. steam and water. A light grey collar around the epicentre of the explosion is believed to be a bore-like elevation of the water surface (tsunami ?) up to $130 \mathrm{~m}$ high, that propagates radially. 3, In $7 \mathrm{~s}$ after piercing the shell, the jets reach their maximum height of $\sim 1 \mathrm{~km}$ and collapse back in to the lake to produce a base surge. 4 . Within $48 \mathrm{~s}$ from the beginning of base-surge propagation, the surge has travelled $600 \mathrm{~m}$ along the lake surface. 5, The surge has lost most of its pyroclastic load, become lighter than the surrounding air and begun to lift buoyantly. 6, The surge cloud has left the ground and convects upward, (b) Explosion in Karymskoye lake viewed from the NW. Collapse of the eruptive column has produced a base surge moving outward along the surface of the lake. Diameter of the base-surge cloud is $1.2 \mathrm{~km}$. Photograph courtesy of Ya. D. Muravyev.

seismograms and barograms of the eruption were obscured by signals from the simultaneous eruption of Karymsky stratovolcano. The total duration of the eruption was 10-20 h. Taking the average observed interval between the explosions as $6 \mathrm{~mm}$, we estimate that 100-200 explosions in all occurred in the lake.

By the end of the eruption, the pyroclastic deposits formed a new peninsula in the northern part of the lake and dammed the headwaters of Karymskaya river. This caused a $2.6 \mathrm{~m}$ elevation of water level in the lake. As a result of the eruption the $\mathrm{pH}$ of the lake water had reached 3.2 and its temperature rose to $28^{\circ} \mathrm{C}$ (Fazlullin et al., 2000). All the fish in the lake died. On 15 May, the pyroclastic dam was breached and a second lahar rushed down the valley of Karymskaya river. A new temporary lake appeared again at the place of the previous one. The friable pyroclastic dam was quickly eroded and the level of the Karymskoye lake quickly fell to that of before the eruption. As a result, at the site of underwater explosions, a perfectly shaped tuff ring emerged from the lake water (Fig. 4a). 

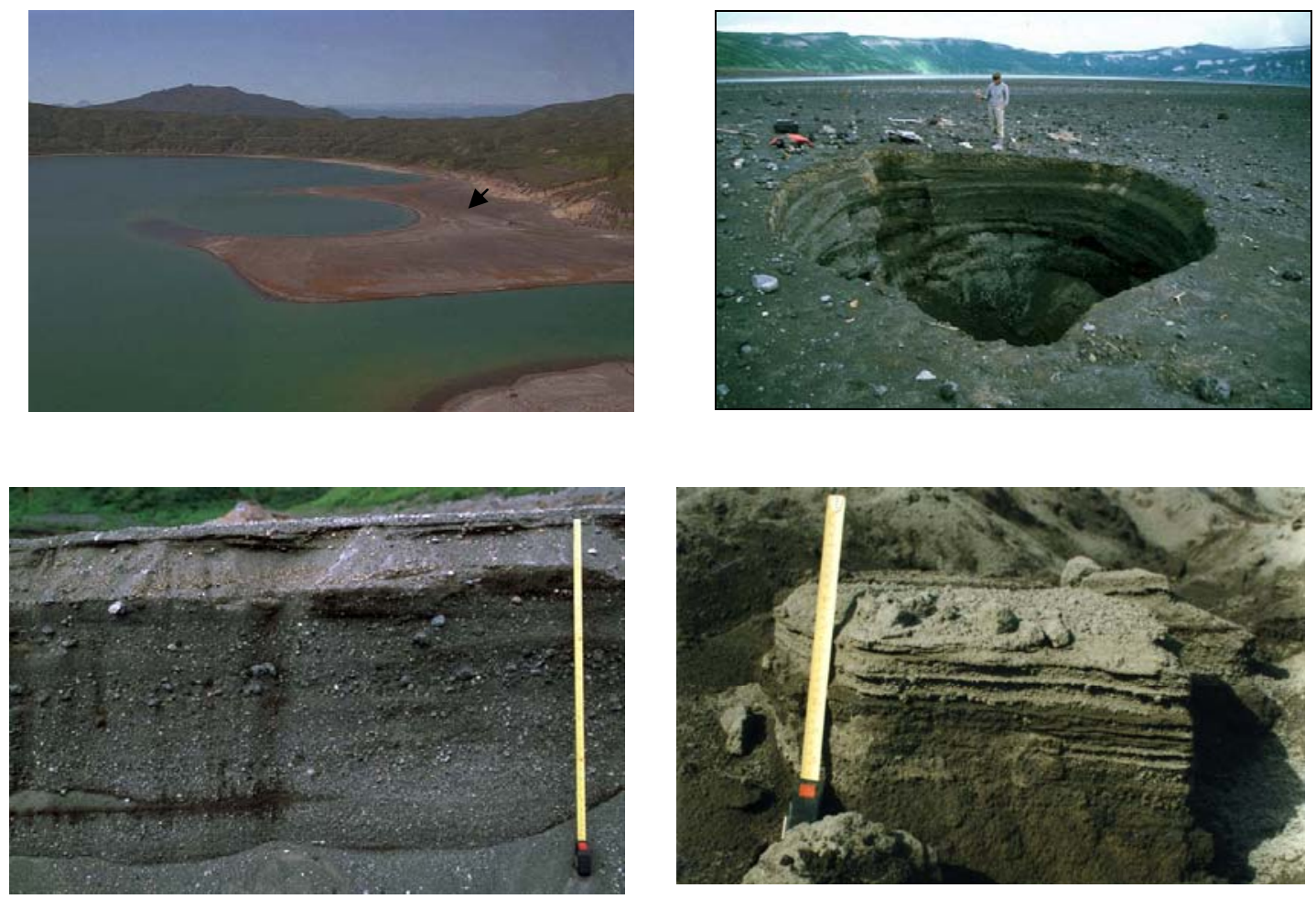

Fig. 4. (a) Tuff ring, with 600-m-diameter crater, formed by 1996 eruption. View from the north-east. (Note strong tsunami erosion on north shore). The largest subsidence pit (site > 120 in Fig. 5) is visible on the surface of the ring (arrow). Eroded pyroclastic dam in headwaters of Karymskaya river is on the right edge of the picture, (b) Layered tuff ring deposit exposed in the deepest subsidence pit (site > 330 in Fig. 5). (Note large number of bombs littering the surface of the tuff ring.) The 1996 crater is to the right, (c) Distal facies of the 1996 tuff ring deposit (site 130 in Fig. 5). Scale is $80 \mathrm{~cm}$ long. Upper friable part is reworked deposits. The 1996 crater is to the left, (d) Parallel layering in the upper part of 1996 distal base-surge deposit. Scale is $25 \mathrm{~cm}$ long. Site 100 in Fig. 5.

After the cessation of the eruption in Karymskoye lake, the eruption of Karymsky stratovolcano continued until the end of April 2000.

\section{TUFF RING MORPHOLOGY}

The eruption formed a partially submerged edifice (Figs $2 \& 4 a$ ), which we refer to as a tuff ring because of its morphological similarity to classic tuff rings (Heiken, 1971). Northern parts of the tuff ring and most of its crater rim are now subaerial, but the crater itself and the southern ring slopes are under water. The highest subaerial parts of the ring lie only a few metres above the present level of the lake. The crater is $650 \mathrm{~m}$ across and $60 \mathrm{~m}$ deep with inner slopes dipping up to $12^{\circ}$ (Ushakov \& Fazlullin, 1998). The outer, southern slope of the tuff ring dips gently outward (up to $10^{\circ}$ ), but the northern slope, which overlaps the pre-eruptive shoreline, is horizontal or even inclined inward towards the crater. The asymmetrical morphology is due to the formation of the edifice on an underwater slope, close to the shore of the lake. The northern, outer edge of the tuff ring is bounded by the steep wall of the caldera, where no deposition occurred (only strong erosion of poorly consolidated bedrock). Further northward from the crater, beyond the eroded caldera wall, deposition of tephra occurred, but the character of the deposit (which we refer to as a distal base-surge deposit) is different from that of the tuff ring deposit.

On the surface of the tuff ring north-north-east of the 1996 crater there is a chain of eight pits (Figs lb \& $4 a, b)$. Most of the pits are shallow depressions 3-5m across, but one of them is $50 \mathrm{~m}$ in diameter with vertical walls $1.5 \mathrm{~m}$ high and a total depth of $\sim 10 \mathrm{~m}$. Along 
trend from the chain of pits, to the north-north-east of the lake, a 2-km-long system of subparallel, vertical fissures was formed during the eruption (Fig. 1 b). The fissures are widest close to the tuff ring (in the upper part up to $4 \mathrm{~m}$ wide) and narrow northward to a few millimetres. The fissures were formed as a result of west-east extension in the region (Leonov, 1998). Geodetic measurements show that the extension was 233 cm (Maguskin el al., 1998), Fissuring was connected with intrusion of a feeder dyke of the eruption $\sim 2.5$ m wide (Fedotov, 1998), and we infer that the pits on the surface of the tuff ring were formed as a result of subsidence after withdrawal of magma from the feeder dyke at the end of the eruption.

The radius of the base of the tuff ring is $\sim 0.8 \mathrm{~km}$. Maximum height of the edifice is estimated at $40-50 \mathrm{~m}$ based on pre-eruptive bathymetry, and the bottom of the crater of the edifice lies close to the pre-eruptive surface, possibly slightly below it. The ratio of the height to the basal diameter of the ring is about 0.03 , which is common for tuff rings (Heiken, 1971). The volume of the edifice $\left(0.047 \mathrm{~km}^{3}\right)$ was roughly calculated as the volume of a truncated cone (height $0.05 \mathrm{~km}$, radii of the base and lop $0.8 \mathrm{~km}$ and $0.32 \mathrm{~km}$, respectively) with subtraction of the volume of the crater (a cone with radius of the base $0.32 \mathrm{~km}$ and height $0.05 \mathrm{~km}$ ). This volume is considered to be a maximum. A similar volume $\left(0.04 \mathrm{~km}^{3}\right)$ was calculated by Muravyev et al. (1998) using a water balance of the volume of the lake during the eruption.

\section{STRATIGRAPHY AND \\ CHARACTERISTICS OF THE 1996 PYROCLASTIC DEPOSITS}

Four types of ejecta were found:

1 proximal thick lapilli ash beds forming the tuff ring;

2 distal base-surge deposits;

3 deposits of distal co-surge fallout;

4 fields of bedrock blocks and juvenile bombs (ballistic material) (Fig. 1b).

\section{Tuff ring deposits}

The deposits forming the tuff ring were studied in the four currently available outcrops: in walls of the two subsidence pits and in the left and right banks of the Karymskaya river, where it breaches the pyroclastic dam (Figs 1 b \& 5). All the outcrops are arranged along

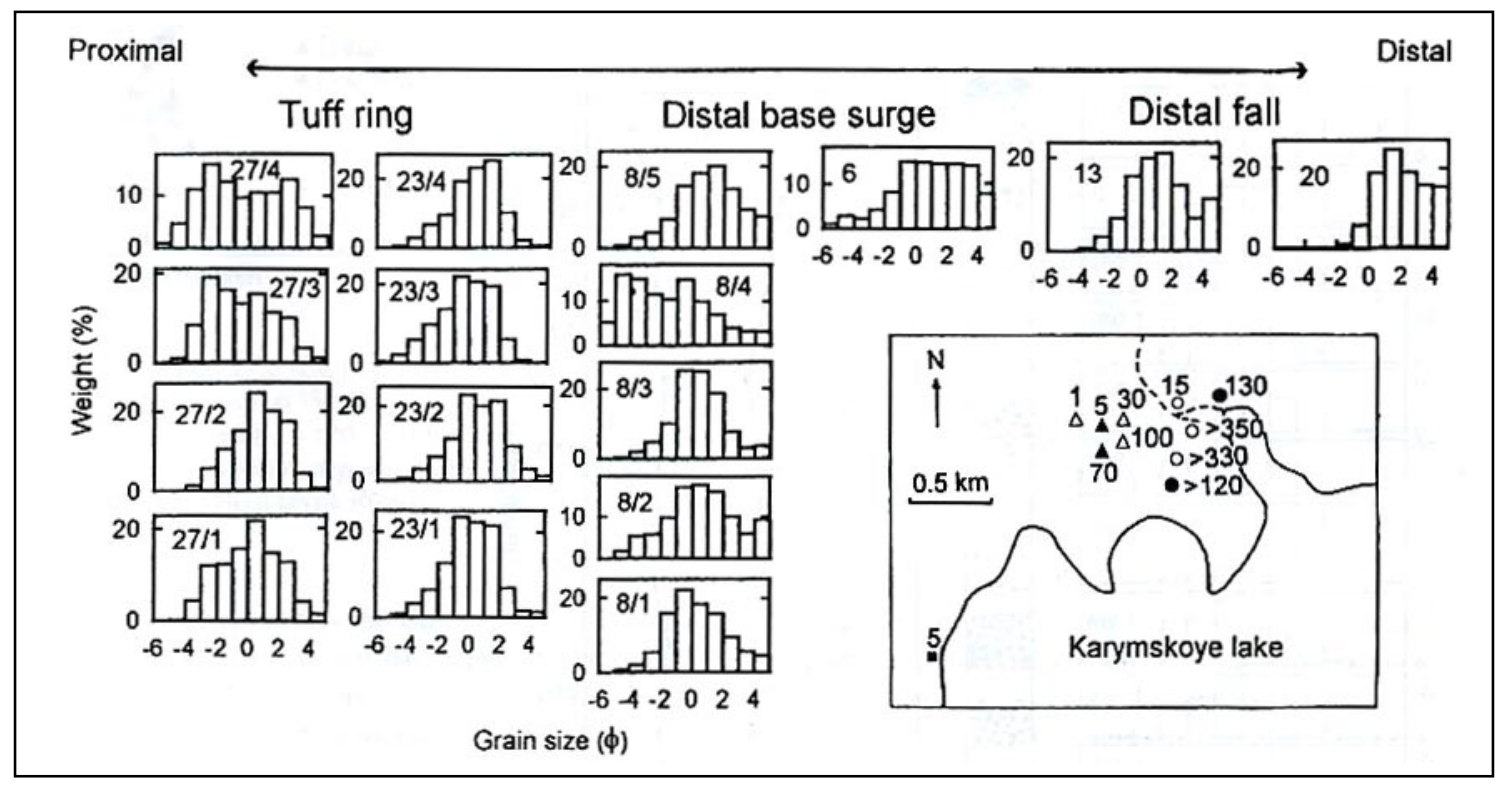

Fig. 5. Examples of grain-size histograms for the 1996 tuff ring, distal base-surge and co-surge fall deposits at various distances from the crater. Numbers on histograms are field number of site/number of layer (from bottom to top). Sketch map insert shows sampling sites: circles, tuff ring; triangles, distal base surge; square, to-surge fall. Filled symbols indicate sites for histograms shown in this figure. Sampling site of the most distal fall is not shown. Numbers on the map show thickness of deposits in centimetres. 


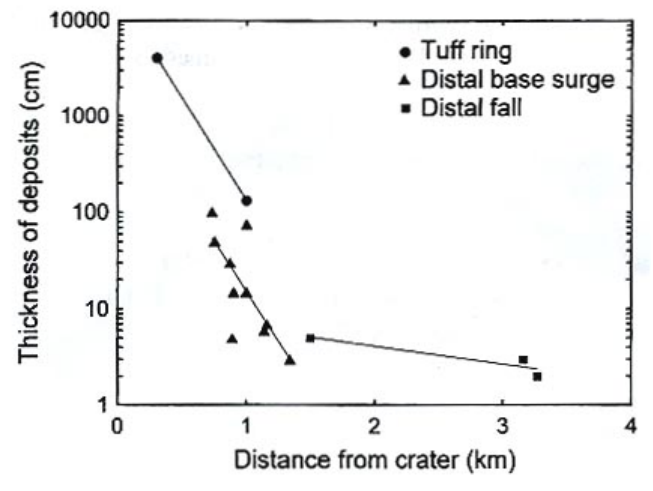

Fig. 6. Thickness of 1996 deposits versus distance from the centre of the crater. Maximum thickness of the tuff ring is estimated at 40-50 m based on pre-eruptive depth of the lake at that location.

a straight line extending radially from the crater. In the three proximal outcrops (up to $750 \mathrm{~m}$ from the centre of the crater) only the upper part (2-3.5 m) of a deposit having a maximum thickness of $50 \mathrm{~m}$ is exposed. The deposit quickly wedges out (Fig. 6) and in the most distal outcrop (1 km from the crater) the full thickness of $1.3 \mathrm{~m}$ is exposed.
In the three proximal outcrops the upper part of the tuff ring is regularly medium- to thick-bedded, dark grey, fines-poor, grain-supported, basaltic ash lapiili and lapilli ash (Figs 4b. 5 \& 7-9: Table 1). Dip of the beds is very gentle; in outcrop they appear subhorizontal. Bed boundaries are usually diffuse, and beds are planar and continuous. Each bed is 10-60 $\mathrm{cm}$ thick, and no erosional discordances have been found. The beds appear to exhibit normal, reverse, or reverse-to-normal grading, but because many contacts between the beds are diffuse, the type of grading is difficult to determine with certainty. It appears that reverse grading is more common for the upper beds and in the lower beds normal grading is most prevalent. Some of the lowermost layers have pronounced separation of a lower lapilli layer from an upper ash layer, and represent bed couplets. The large lapilli are mostly irregular in shape and are angular to sub-rounded. No sag structures have been found under even the largest clasts.

Grain-size distributions of the deposits are commonly unimodal with coarse- to medium-ash modes ( 4 to -1 phi; Figs 5 \& 7, Table I). A very low content of fines is typical of the deposits. In the upper parts of the sections, where the deposit is notably coarser, there is usually an additional lapilli mode (- 1 to -6 phi). The deposits are moderately to poorly sorted (Fig. 8).
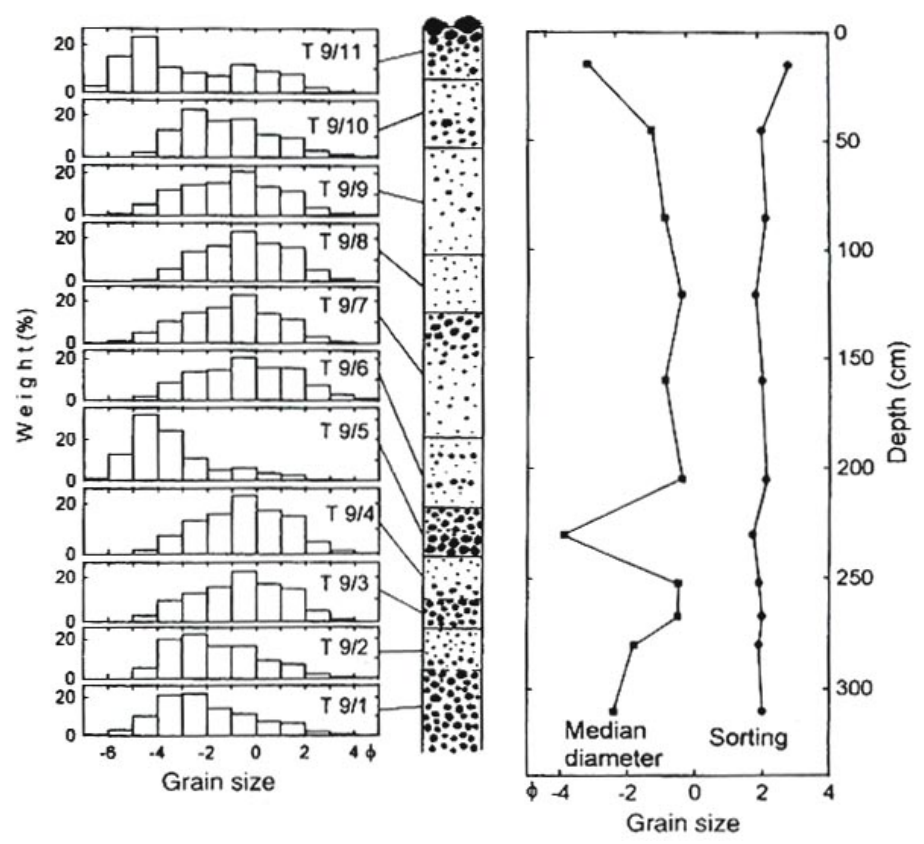

Fig. 7. Sections and grain-size data of the 1996 tuff ring deposit in the deepest subsidence pit (Fig.4b and site 330 in Fig. 5). 
Eruptions in Karymskoye lake, Russia

Fig. 8. Relationship between sorting and median diameter (Inman coefficients) for the deposits of the first (4800 ${ }^{14} \mathrm{C}$ yr BP), second (4800

${ }^{14} \mathrm{C}$ yr BP) and 1986 eruptions.

Dashed line is 'Surtseyan' field after Walker \& Croasdale(1972). (a)

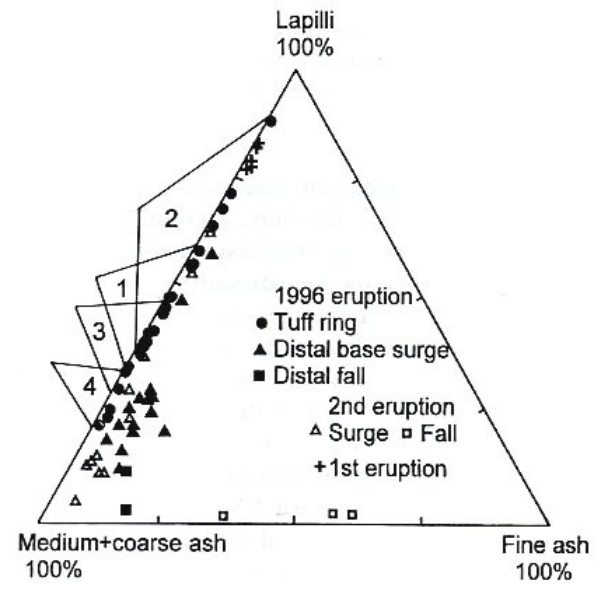

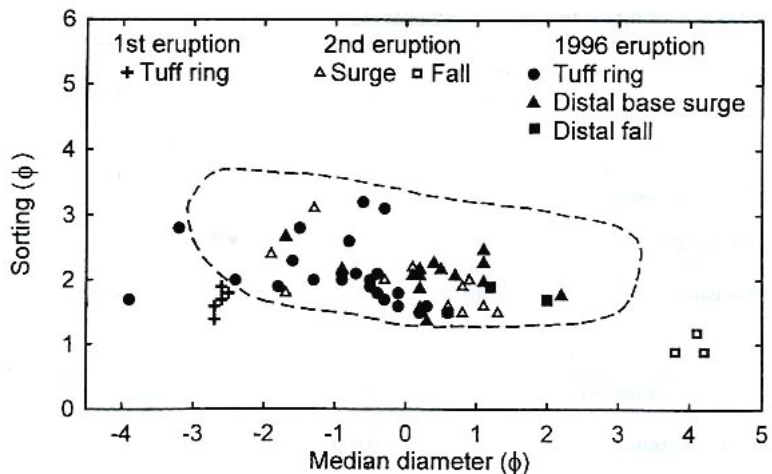

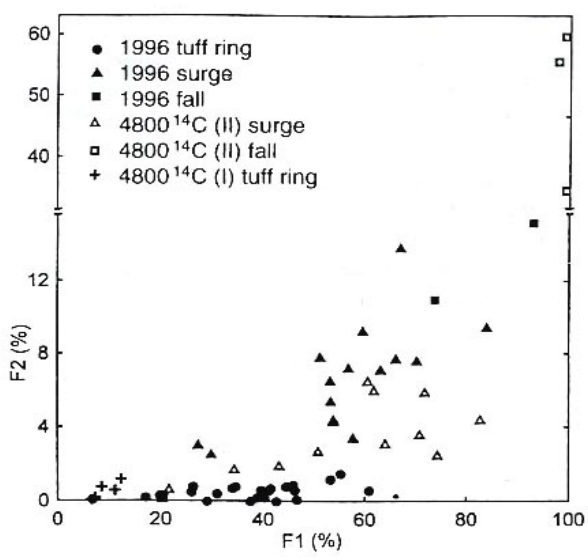

Fig. 9. (a) Percentage of lapilli $(>2 \mathrm{~mm})$, medium + coarse ash $(0.063-2 \mathrm{~mm})$ and fine ash $\{<0.063 \mathrm{~mm})$ in the pyroclastic deposits of the first (4800 $\left.{ }^{14} \mathrm{Cyr} \mathrm{BP}\right)$, second $\left(4800{ }^{14} \mathrm{C}\right.$ yr BP) and 1996 eruptions. Numbers 1 , 2. 3, and 4 outline 1996 tuff ring deposits sampled al sites $>120,>330,>350$, and 130, respectively, in Fig. 5. (b) Relationship between $F_{1}$ (fraction $<1 \mathrm{~mm}$ ) and $F_{2}$ (fraction $<1 / 16 \mathrm{~mm}$ ) in deposits of the 1996, and first (I) and second (II) $4800{ }^{14} \mathrm{C}$ yr BP eruptions in Karymskoye lake. (Note that $\mathrm{F}_{2}$ axis has a break showing very fine-grained fall deposits of the second eruption.)

Grain-size characteristics of the deposit from proximal outcrops are very similar; upper layers of the deposit commonly are more poorly sorted than lower ones. On a plot of lapilli /medium + coarse ash/fine ash (Fig. 9a) there is some inconsistent tendency for deposits to become less coarse with distance from the crater. The studied material was deposited near the water-air interface. We infer that normal grading and bed couplets of the lower beds may result from deposition in a subaquatic environment.
Each bed of the tuff ring is believed to represent the deposit of a single explosion. Taking nominal deposit thickness to be $50 \mathrm{~m}$, and average proximal bed thickness to be $25 \mathrm{~cm}$, it can be estimated that 200 explosions occurred, averaging $\sim 2 \times 10^{5} \mathrm{~m}^{3}$ of tephra per explosion. This is, of course, a very rough estimation, based on extrapolation of stratigraphy of the upper part of the tuff ring to the unexposcd $90 \%$ of the deposit. But it coincides with the previous estimation (100-200 explosions), based on total duration of the 
Table 1. Granulometric characteristics of clastic deposits of eruptions in Karymskoye lake

\begin{tabular}{lccccccc}
\hline & $\begin{array}{c}\text { Number } \\
\text { of samples }\end{array}$ & Sorting (phi) & $\begin{array}{c}\text { Median } \\
\text { diameter (phi) }\end{array}$ & Lapilli(\%) & $\begin{array}{c}\text { Coarse }+ \\
\text { medium ash (\%) }\end{array}$ & F1(\%) & F2 (\%) \\
\hline 1996 tuff ring & 24 & $1.5-3.2$ & $-3.9-0.6$ & $20.0-87.0$ & $13.0-79.5$ & $6.8-60.9$ & $0-1.5$ \\
& & 2.1 & -0.9 & 44.5 & 55.0 & 36.6 & 0.5 \\
1996 distal surge & 15 & $1.4-2.7$ & $-1.7-2.2$ & $2.9-47.7$ & $38.9-79.6$ & $27.2-84.0$ & $2.6-13.9$ \\
& & 2.1 & 0.4 & 23.8 & 68.0 & 56.4 & 6.6 \\
1996 distal fallout & 2 & $1.7-1.9$ & $1.2-2,0$ & $1.3-9.8$ & $79.2-83.6$ & $73.8-93.1$ & $11.0-15.2$ \\
& & 1.8 & 1.6 & 5.6 & 81.4 & 83.4 & 13.1 \\
1996 tsunami & \multirow{2}{*}{15} & $0.7-2.1$ & $-1.1-2.4$ & $0-52.2$ & $46,1-99.1$ & $22.6-100$ & $0.3-3.3$ \\
& & 1.2 & 0.7 & 15.3 & 83.2 & 68.7 & 1.4 \\
1996 lahar & \multirow{2}{*}{3} & $0.8-2.3$ & $-1.4-3.6$ & $0-56.4$ & $43.6-90.9$ & $23.5-100$ & $0-28.1$ \\
& & 1.3 & 1.7 & 18.8 & 68.8 & 74.5 & 12.4 \\
Second eruption: surge & \multirow{2}{*}{12} & $1.5-3.1$ & $-1.9-1.3$ & $3.0-63.3$ & $36.7-92.6$ & $20.3-82.7$ & $0.1-6.5$ \\
& & 1,9 & 0.1 & 26.6 & 70.1 & 54.7 & 3.3 \\
Second eruption: fall & \multirow{2}{*}{3} & $0.9-1.2$ & $3.8-4.2$ & $0.1-0.6$ & $40.0-65.5$ & $97.7-99.3$ & $34.4-59.6$ \\
& & 1.0 & 4.0 & 0.4 & 49.8 & 98.7 & 49.8 \\
First eruption: tuff ring & \multirow{2}{*}{5} & $1.4-1.9$ & $-2.7-(-2,5)$ & $76.5-82.2$ & $17.8-22.9$ & $6.6-12.3$ & $0.1-1.2$ \\
& & 1.7 & -2.6 & 79.0 & 20.5 & 9,2 & 0,5 \\
\hline
\end{tabular}

Numbers on the first line are the lowest and highest values, those on the second line give the average value. Sorting and median diameter after Inman (1952): lapilli, $<-1$ phi ( $>2 \mathrm{~mm})$; coarse and medium ash, from -1 phi to +4 phi $(0.063-2$ $\mathrm{mm}) ; \mathrm{F}_{1}>0$ phi $(<1 \mathrm{~mm}) ; \mathrm{F}_{2}>4 \mathrm{phi}(<0.063 \mathrm{~mm})$, $\mathrm{phi}=-\log _{2}$ (diameter in millimetres).

eruption and average interval between explosions, and thus seems reasonable.

The deposit in the most distal outcrop (Fig, 4c) is different from that described above. It has smaller median diameter and better sorting. The deposit is mostly ash with discontinuous trains of coarse lapilli. Unlike the proximal deposit, this deposit lacks well-developed parallel bedding. Instead it has low-angle, ill-defined layering with distinct lateral grain-size variations. Laterally this deposit transforms into deposits of distal base surges.

The characteristics of the tuff ring deposit are not entirely consistent with any of the depositional processes previously known to form tuff rings. Moderate sorting and lack of fines makes the deposit similar lo proximal fall deposits of dry hydroclastic eruptions (e.g. LT1 facies of Sohn \& Chough, 1989), but observations and videotape show that the eruption in Karymskoye lake was very wet. Deposition directly from falling tcphra-finger jets of Surtseyan eruption results in poorly sorted, fines-rich deposits (e.g. facies C of Sohn \& Chough, 1992) because aerodynamic sorting in the jets is minimal as a result of cohesion of wet tephra, high particle concentration and rapid emplacement. Absence of bomb sags also suggests that the tuff ring beds are not of fall origin. Moreover, proximal fall deposits of hydroclastic eruptions commonly form tuff cones with steeply dipping beds (Sohn \& Chough, 1992), which is not the case for Karymskoye. The very gentle dip of the 1996 tuff ring beds, their rather consistent thickness over large distances, and their grain-size characterstics support an origin by deposition from pyroclastic density currents. Among gas-pyroclastic density currents only some extremely energetic dry surges can deposit material strongly depleted in fines (e.g. layer B of the 1956 directed blast deposits of Bezymianny volcano; Belousov, 1996). But surges of the 1996 eruption were wet, poorly inflated and relatively weak; if they had deposited the tuff ring, the deposit would be fines rich (like. e.g. LT3 facies of Sohn \& Chough, 1989).

We suggest that the studied tuff ring deposit was formed by multiple (periodic) flows of a hyperconcentrated water pyroclastic mixture, which moved radially from the crater area (Smith, 1986). The absence of scour and channelling indicates that the flows were depositional and unconfined. It is likely that the flows had different concentrations of solid particles; the more dilute flows left normally graded layers, whereas the most concentrated flows show reverse grading formed by basal shear and grain-dispersive forces (Lowe, 1982). In the distal zone the deposits of the tuff ring were formed by relatively dilute flows, which lost much of their pyroclastic load in the proximal zone. Origin of the flows is attributed to very wet base surges of the eruption. We suggest that the flows existed as peculiar water pyroclastic underflows in the basal parts of the surges. Flows of similar origin were probably witnessed during some explosions of Surtsey (Thorarinsson. 1964; p. 43): 'explosions were often 
followed by greyish-white cloud avalanches which rolled over the crater rims and, after the island had grown to some appreciable height, they sometimes spread a few hundred metres out over the sea. Sometimes the explosions ejected so much sea water over the crater rims that mud streams ran all the way down to the beach."

\section{Surface layer of the tuff ring}

The surface layer of the tuff ring is different from the deposits that form the upper (studied) part of the tuff ring. The layer is $\sim 1 \mathrm{~m}$ thick and strongly enriched in coarse lapilli and basaltic bombs up to $1 \mathrm{~m}$ across, which were ejected at the end of the eruption (Fig. 4b). The 'Ballistic material' section describes the bombs in greater detail.

Aerial images of the tuff ring reveal that its surface has large-scale ripples in several places. The ripples are very gentle, almost flat patches of coarse lapilli and bombs, and areas between the patches are covered by ash. The ripples, with wavelengths of 4-6 m, are elongate parallel to the crater rim. They were formed at the end of the eruption only; ripples were found nowhere lower in the deposit. They were probably formed by tsunami waves that redistributed coarse-grained clasts on the surface of the ring (see below).

The underwater surface of the tuff ring is mantled by a layer of pale grey fine vitric ash (Md 6.7 phi; sorting $1.5 \mathrm{phi}$ ) up to $30 \mathrm{~cm}$ thick. The layer was studied in several locations along the crater rim where it now lies onshore because the level of the Karymskoye lake fell after the eruption. This layer represents the most fine-grained pyroclastic products of the eruption, and it is inferred that when the eruption ceased, this material, along with fines eroded from the shores by the tsunami waves (see below), slowly settled in the lake to form the fine ash layer.

\section{Distal base-surge effects and deposits}

In the distal zone the surges attacked the steep northern shore of the lake. They sandblasted bushes as far as $1-1.3 \mathrm{~km}$ from the vent (Fig. lb). Damaged bushes show that the surges climbed gradients of up to $40^{\circ}$ on the caldera wall. The highest elevation reached by the surges is $\sim 150 \mathrm{~m}$ above the level of the lake. Close to the crater, all thin branches of the bushes were broken off and carried away by surges; only thick branches remain. The sides facing the crater were debarked and the wood was pitted. Most of the branches show no signs of scorching, but a few are slightly browned.
Hence we estimate the temperature of the surges to have been $<200^{\circ} \mathrm{C}$ (Banks \& Hoblitt, 1981). Most of the damaged bushes died but a few resumed their growth after the eruption. The relatively low temperature of the surges explains the preservation of a thick layer of snow under the surge deposits. The presence of the snow also shows that the surges did not erode the underlying surface substantially. Near the limits of their propagation, the surges dried and broke upper thin branches of the bushes. The lower branches were not damaged at all, probably because they were protected by deep snow.

Pyroclastic deposits in the area of damaged bushes are notably different from the deposits of the tuff ring. Among the bushes deposits are moderately sorted dark grey basaltic lapilli ash with abundant fines (Figs 4d, 5.8 \& 9; Table 1), The deposit comprises a sequence of two to three major, grain-supported parallel beds, each 10-35 cm thick, and several minor ones, each $<1 \mathrm{~cm}$ thick (Fig. $4 \mathrm{~d}$ ). Bed boundaries are usually well defined. The beds are massive or with poorly developed planar or low-angle undulatory lamination. The lowermost layer of the deposits in places contains a considerable number of uncharred fragments of plants, but in upper sections these are rare. In contrast to those of the tuff ring deposit, the deposits of distal surges are very friable. Grain size of the deposit is commonly unimodal (between -1 phi and 2 phi), sometimes with an additional poorly developed fine grained mode ( $>4 \mathrm{phi}$ ). The maximum total thickness of the deposit is $1 \mathrm{~m}$, but this very quickly decreases both on steep slopes and with distance from the crater (Fig. 6). The area covered by the surge deposit onshore is $0.4 \mathrm{~km}^{2}$ and its volume is $\sim 10^{5} \mathrm{~m}^{3}$. Laterally the base-surge deposits are replaced by deposits of distal co-surge fallout.

The surges' effects and deposits show that the base surges were relatively weak, cold, and non-erosive in distal areas. Pyroclastic particles from the surges were deposited 'grain by grain', but with little or no traction before deposition.

\section{Distal co-surge fallout}

The fall deposit extends from the 1996 tuff ring to the south-east (Fig. 1b). Everywhere, the dark grey, basaltic fall of the sub-lacustrine eruption covers 1 -cm-thick, light grey, andesitic ash of the first explosions of Karymsky stratovolcano. The maximum thickness of the co-surge fall deposit onshore is $5 \mathrm{~cm}$ at the place where the base-surge deposit transforms into the fall deposit. The transformation is marked by 
a disappearance of both internal lamination, characteristic of the surge deposit, and damage to bushes, which indicates high-speed lateral transport of pyroclastic particles. The thickness of the fallout deposit declines rapidly with distance (Fig. 6): on the southern shore of the lake it is only $1 \mathrm{~cm}$ thick. The approximate volume of the fall deposit is $0.001 \mathrm{~km}^{3}$.

The fall deposit is massive, moderately sorted medium-coarse ash with a small admixture of fine ash and lapilli (Figs 5, 8 \& 9; Table 1). Close to the vent, grain-size characteristics of the deposit are similar to those of the most fine-grained surge deposits. Further from the source, the fall deposit becomes finer grained and better sorted. In the fall deposit there are also a few centimetre-sized lapilli, though they do not influence the grain-size data because of their rarity. On the south-east shore of the lake, where the fall deposit consists of medium-grained ash, the diameter of the 10 largest clasts picked up in an area of $\sim 0.2 \mathrm{~km}^{2}$ ranges from 18 to $30 \mathrm{~mm}$ (average $21 \mathrm{~mm}$ ).

The lateral transition of the surge deposit into the fallout deposit, the similarity of grain-size distributions of the fall and the most fine-grained surge deposits, and observations of the eruption all suggest that convectively buoyant clouds of decelerated surges were the main source of the fall deposit. The carrying capacity of such clouds was very low, which explains the small volume of the resulting co-surge fallout.

Although accretionary lapilli are common in phreatomagmatic deposits (Fisher \& Schmincke, 1984; Schumacher \& Schmincke, 1991), none were found in the surge or fall deposits. The reason could be that there was excess water in the eruption clouds and base surges (Schumacher \& Schmincke, 1995). An alternative explanation is suggested by the very low air temperature during the eruption $\left(<-10^{\circ} \mathrm{C}\right)$. Steam droplets in the eruption cloud may have frozen immediately upon condensation to form ice, which would have prevented formation of accretionary lapilli. Several observations of the fail deposit soon after the eruption (Ya. D. Muravyev \& S. M. Fazlullin, personal communication) indicate that initially the deposits were a mixture of pyroclastic particles and grains of dirty ice.

\section{Ballistic material}

We estimate the volume of ballistic material to be $<$ $2 \%$ of the total erupted volume. The most distal ballistic material fell $1.3 \mathrm{~km}$ from the centre of the 1996 crater ( $\sim 1 \mathrm{~km}$ from the crater rim) (Fig. 1b). We distinguish four types of ballistic material: bombs of juvenile basalt (dominant); blocks of hydrothermally altered breccia (abundant): blocks of ice (some); and bombs of remelted old rhyolite (very few).

Bombs of juvenile basalt constitute $>90 \%$ of all ballistic material. They densely cover a significant part of the surface of the tuff ring (Fig. 4b) and are loosely scattered beyond its limits. In sections of the tuff ring, bombs are absent, suggesting that they were ejected only at the end of the eruption. The bombs have irregular, but approximately equidimensional shapes. Most have a scoriaceous outer layer several centimetres thick, whereas their interior is commonly poorly vesiculated, sometimes with inclusions of centimetresized xenoliths of country rocks. Such an internal structure is unusual. In most cases the outer layer of a bomb quickly solidifies, forming a glassy crust (Francis, 1993), and the internal parts solidify more slowly, providing more time for vesiculation, which breaks the outer glassy crust and forms bread-crusted bombs. The dense cores of the 1996 bombs consist of the same fresh basalt as the vesiculaled outer part. We term them 'scoria-crust bombs', and contrast them with cored bombs, in which an accidental clast forms a core enclosed within freshly vesiculated lava.

This peculiar structure, the presence of xenoliths of country rocks in the bombs, and deposition at the end of the eruption, suggest that the 1996 bombs represent solidified magma from the conduit wall, which was ripped off and enveloped by fresh magma. The previously congealed cores were unable to vesiculate, but the coating of fresh melt vesiculaled strongly, thus producing the scoriaceous crust. Some of the basaltic bombs of the eruption are of cauliflower type, typical of phreatomagmatic eruptions (Fisher \& Schmincke, 1984).

The diameter of the basaltic bombs ranges from 10 to $60 \mathrm{~cm}$, with a few up to $1 \mathrm{~m}$. The largest bombs occur at intermediate distances from the vent (Fig. 10), but this distribution may not be original, because most bombs in the proximal area (on the surface of the tuff ring) arc inferred to have been redistributed and broken by the tsunami waves. Thus the basaltic bombs may have originally decreased in size with distance from the vent.

Such wave reworking could also he responsible for the absence of impact structures on the surface of the ring. Beyond the tuff ring (onshore) basaltic bombs left impact craters up to $1 \mathrm{~m}$ across. Some bombs penetrated a snow pack $>1 \mathrm{~m}$ thick and up to $0.7 \mathrm{~m}$ of frozen soil. Bushes broken and uprooted by the projectiles show no signs of scorching, showing that the bomb surfaces were not incandescent at the moment of impact. 


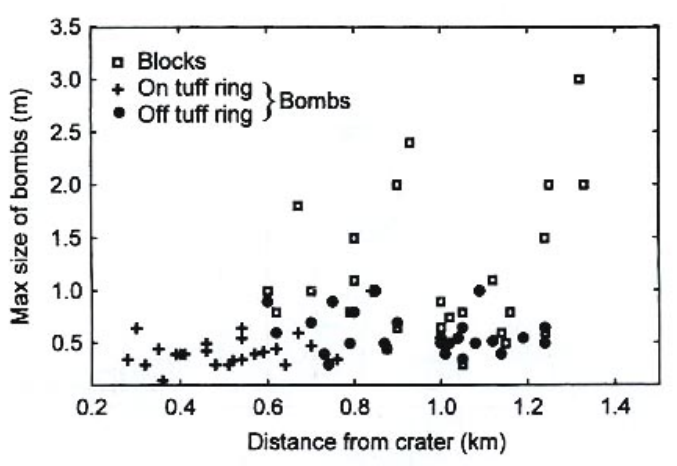

Fig. 10. Maximum size of ballistic material from 1996 eruption versus distance from the crater. Blocks arc hydrothermally altered country rock; bombs are juvenile basalt.

Blocks of hydrothermally altered breccia constitute $<10 \%$ of all ballistic material. The diameter of these blocks typically ranges from $10 \mathrm{~cm}$ to $2 \mathrm{~m}$, with a few up to $3 \mathrm{~m}$. The largest blocks were ejected to a maximum distance of $1.3 \mathrm{~km}$ (Fig. 10), where they produced impact craters up to $8 \mathrm{~m}$ wide and $2 \mathrm{~m}$ deep. Several lines of evidence suggest that these blocks were ejected by the first, vent-clearing explosion(s) of the eruption:

1 the blocks are distributed mostly beyond the limits of the tuff ring and. are extremely rare on its surface and inside the tuff ring deposits-it is likely that in the proximal zone blocks are buried under the tuff ring deposit;

2 the blocks show no signs of contact with basaltic melt; 3 there is no basaltic ash of the eruption under the soil that was ejected from the impact craters.

In summer 1996, when we investigated the deposits, we discovered that among the impact craters formed at the beginning of the eruption there are several craters (up to $1.8 \mathrm{~m}$ across and $2 \mathrm{~m}$ deep) that do not contain (confirmed by digging) any 'coupled' ballistic material, and that there are no blocks nearby that could have formed the craters and bounced away. We infer that these 'empty' craters were formed by large blocks of ice that later melted. Several impact craters containing large blocks of ice were observed immediately after the eruption (Ya. D. Muravyev. personal communication]. The ice blocks represent fragments of an ice layer that covered the lake before the eruption.

Several exotic bombs of pumice-like remelted old rhyolite contained in and/or mixed with juvenile basalt also occur. These bombs, up to $2 \mathrm{~m}$ across, are concentrated along the shoreline of the lake. They did not produce any impact structures, and, having an average density less than that of water, they probably initially fell into the lake and then floated for some time so that their present distribution is not original.

\section{Composition}

Material ejected by the 1996 eruption is composed of juvenile basalt, remelted rhyolite, and other accidental clasts. Petrography of the 1996 products was studied in detail by Grib (1998). More than $95 \%$ of the ejected material is juvenile calc-alkaline basalt $\left(52-53 \% \mathrm{SiO}_{2}\right.$; Table 2).

A small amount of white, pumice-like rhyolite (Table 2), which either forms tiny inclusions in juvenile basalt or comprises rare volcanic bombs coated and/or mixed with juvenile basalt, is interpreted as recycled material—old rocks, remelted and vesiculated as a result of contact with hot basaltic magma. The older rocks were probably obsidian or obsidian tuff entrained by the ascending magma from the walls of the feeding fissure where it dissected rocks mantling the caldera floor. Obsidian clasts with the same composition as that of the rhyolitic bombs are common in late Pleistocene pyroclastic flow deposits formed by eruptions during the formation of Akademiya Nauk caldera (Table 2), and outcrops of the obsidianbearing pyroclastic flows are abundant along the northern shore of the lake. Our experiments with heating

Table 2. Major-element analyses of ejecta from eruptions in Karymskoye lake

\begin{tabular}{lrrrrrr}
\hline & \multicolumn{1}{l}{$l$} & \multicolumn{1}{l}{ l } & \multicolumn{1}{l}{5} & \multicolumn{1}{l}{6} \\
\hline $\mathrm{SiO}_{2}$ & 53.00 & 75.71 & 75.86 & 52.52 & 55.70 & 53.00 \\
$\mathrm{TiO}_{2}$ & 0.86 & 0.19 & 0.18 & 1.05 & 0.84 & 0.59 \\
$\mathrm{AI}_{2} \mathrm{O}_{3}$ & 19.98 & 13.17 & 13.30 & 17.88 & 16.63 & 16.94 \\
$\mathrm{Fe}_{2} \mathrm{O}_{3}$ & 1.74 & 0.06 & 0.31 & 2.09 & 1.62 & 2.37 \\
$\mathrm{FeO}$ & $5 . \mathrm{R} 3$ & 1.29 & 2.16 & 7.07 & 6.07 & 7.37 \\
$\mathrm{MnO}$ & 0.12 & 0.04 & 0.05 & 0.15 & 0.15 & 0.13 \\
$\mathrm{MgO}$ & 4.20 & 1.20 & 0.24 & 5.88 & 5.28 & 5.76 \\
$\mathrm{CaO}$ & 10.94 & 1.50 & 1.26 & 10.36 & 10.14 & 10.80 \\
$\mathrm{Na} 2$ & 2.70 & 3.44 & 4.11 & 2.35 & 2.76 & 2.35 \\
$\mathrm{~K}_{2} \mathrm{O}$ & 0.62 & 2.19 & 1.97 & 0.68 & 0.93 & 0.68 \\
$\mathrm{H}_{2} \mathrm{O}$ & 0.20 & 0.74 & 0.38 & 0.16 & 0.10 & 0.24 \\
$\mathrm{P}_{2} \mathrm{O}_{5}$ & 0.16 & 0.08 & 0.06 & 0.13 & 0.17 & 0.16 \\
$\mathrm{Sum}$ & 100.35 & 99.61 & 99.88 & 100.32 & 100.39 & 100.39 \\
& & & & & & \\
\hline
\end{tabular}

Analysed by L. A. Kartasheva. Institute of Volcanology, Petropavlovsk-Kamchatsky using wet chemistry methods.

1, Basaltic bomb of the 1996 eruption; 2, rhyolitic bomb of the 1996 eruption; 3. obsidian from pyroclastic flows erupted in the range 28 -48 ka during formation of the Akademiya Nauk caldera; $4,4800^{14} \mathrm{C}$ yr BP surge deposits of second eruption; $5,4800{ }^{14} \mathrm{C}$ yr BP bomb of second eruption; $6,4800{ }^{14} \mathrm{C}$ yr BP tuff ring deposits of first eruption. 
of the obsidian have shown that at $850^{\circ} \mathrm{C}$ it melts and strongly froths. The resultant perlite resembles material of the rhyolitic bombs ejected by the eruption. 'Pumice' of similar origin, generated by heating of old rocks, was reported from eruptions of Ruapehu volcano in 1975 (Nairn et al., 1979) and from a submarine eruption off Izu Peninsula, Japan, in 1989 (Yamamoto et al., 1991).

Blocks of greenish hydrothermally altered breccia are dominant among the other accidental clasts ejected by the eruption. They probably represent a tectonic breccia of the north-north-east fault along which the feeding dyke of the eruption was intruded.

\section{Vesicularity and morphology of juvenile clasts}

Vesicularity of the basaltic clasts from the 1996 eruption was determined according to the procedure developed by Houghton \& Wilson (1989) and Hoblitt \& Harmon (1993). Combined data from three samples, of 30 clasts each, collected from the tuff ring deposit (one sample) and distal base-surge deposit (two samples) are presented in Fig. 11. The deposits have vesicularity indices of $7-63 \%$ (mean 34\%). This range is appreciably larger than in most Strombolian deposits (Houghton \& Wilson, 1989), thus indicating fragmentation of a variably vesiculated magma rather than wholly 'magmatic' fragmentation simply by bursting of bubbles.

Scanning electron microscope images of sand-sized particles of juvenile basalt display different clast shapes and degrees of vesiculation (Fig. 12). Poorly vesiculated particles commonly have small (5-90 um), spherical vesicles that are isolated from one another by thick walls. Such particles commonly have an equant, blocky morphology, and are bounded by planar surfaces that cut vesicles (Fig. 12a). The surfaces have peculiar chip-marks, and some are intersected by thin, curved cracks (Fig. 12b \& c). The character of these surfaces shows that the vesiculated glass was brittle during fragmentation. Some particles have large, irregular vesicles up to $0.3 \mathrm{~mm}$, which were formed by coalescence of smaller bubbles (Fig. 12d) and can be partially bounded by smooth, curved surfaces, which were originally the inner surfaces of those large vesicles. Sometimes such smooth surfaces can form almost the whole surface of a particle (Fig. 12e). In this case the particle shape reflects mostly surface-tension moulding of liquid melt. Highly vesiculated particles have multiple, irregular bubbles of different sizes, which are separated by thin walls (Fig. 12f). The walls are frequently broken and the bubbles are intercon-

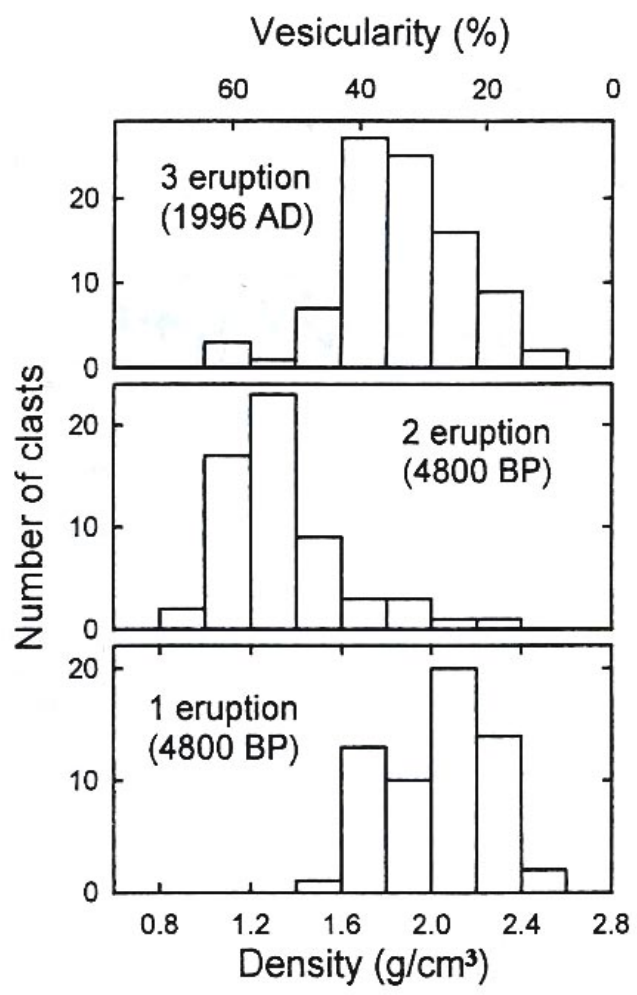

Fig. 11. Density-vesicularity histograms for juvenile lapilli collected from deposits of the first (60 clasts), second (60 clasts) and third (90 clasls) phrealomagmatic eruptions in Karymskoye lake. Measured clasts are 1-3 cm across. Vesicularity values are derived using a dense rock equivalent value of $2.8 \mathrm{~g} \mathrm{~cm}^{-3}$.

nected. The broken walls sometimes show features of plastic behaviour where gas burst from one bubble to another towards the surface of the grain (Fig. 12g). Overall the shape of such particles is scoriaceous, determined mostly by processes of magma vesiculation. A few particles are abraded and notably rounded (Fig. 12h).

Ash grains typically have micron-sized flakes adhering to their surfaces. Such flakes commonly have a blade-like shape with sharp edges. They were formed during brittle fragmentation of basaltic glass (Fig. 12b \&c). Some of the flakes are demonstrably in situ, because they are not completely separated from the parent grains.

The surface morphology of the 1996 juvenile particles is typical of products of phreatomagmatic basaltic 
(a)
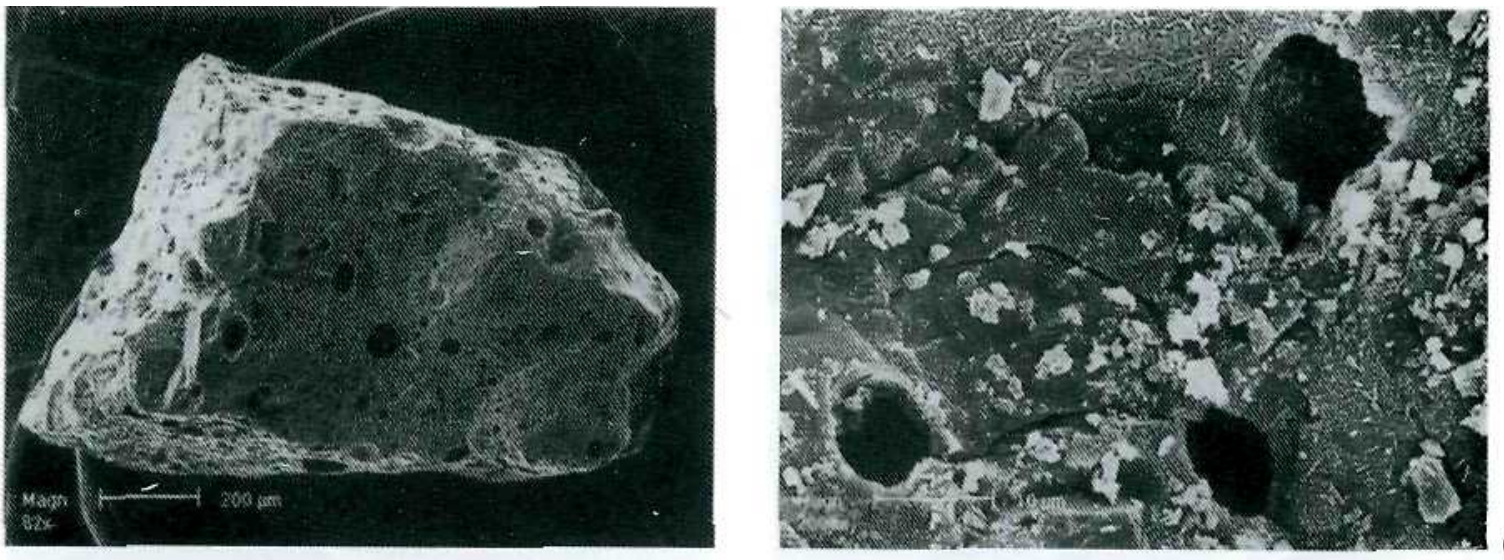

(b)

(c)
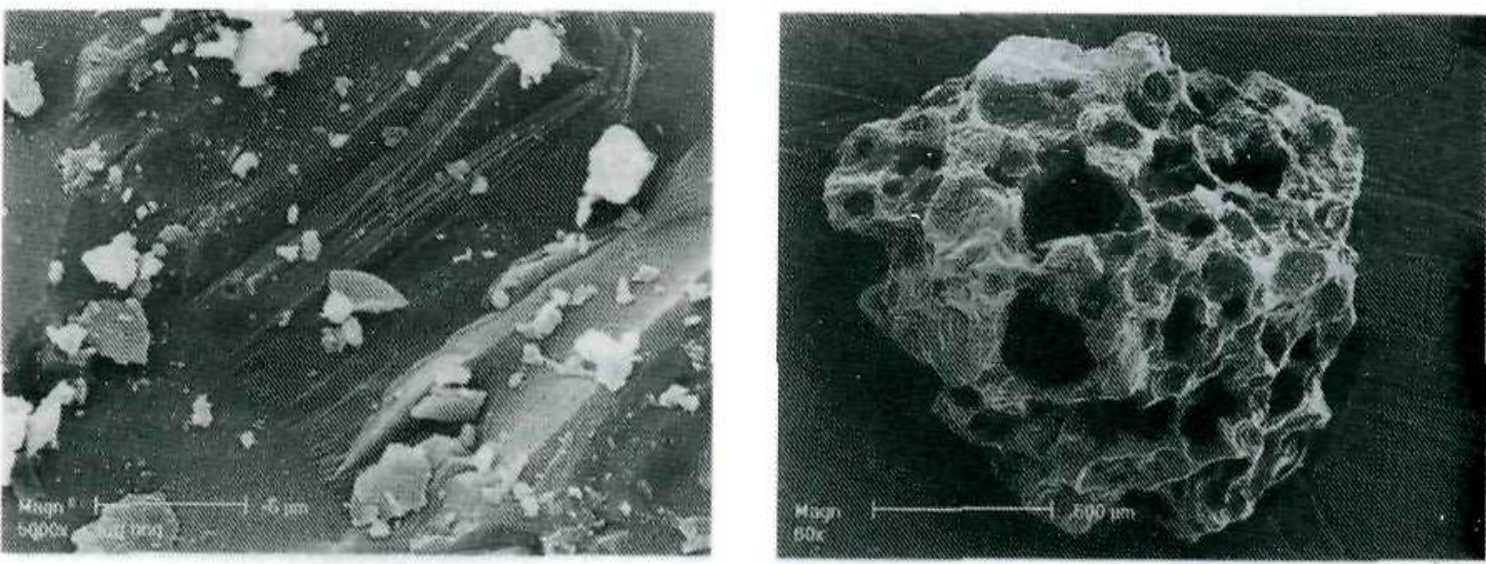

(d)
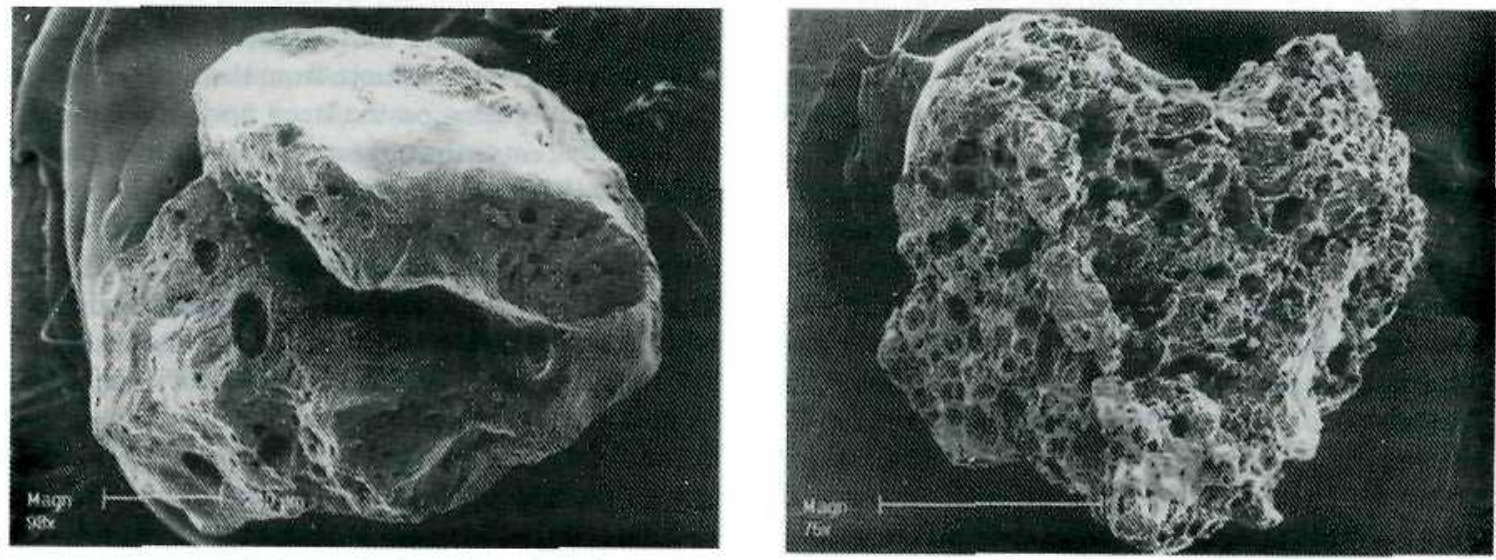

Fig. 12. Scanning electron microscope images of surfaces of sand- sized juvenile basaltic particles from the 1996 tuff ring deposit (a-h) and surge deposit of the second $4800^{14} \mathrm{C}$ yr BP eruption (i). (a) Blocky, poorly vesiculaled particle formed by fragmentation of already brittle basalt as a result of water -magma interaction, (b, c) Small-scale surface features of particle in (a). Blade-like flakes of glass and marks of surface cracking and chipping formed during brittle disruption of basaltic glass. Some of the flakes were not completely separated from the parent surface, (d) Particle with large, irregular vesicles up to $0.3 \mathrm{~mm}$ formed by coalescence of smaller bubbles, (e) Particle of poorly vesiculated basalt formed by both forces of surface tension of liquid melt and subsequent brittle fragmentation. Probably represents droplets of basalt injected into water as a result of low-energy water-magma interaction, (f) Highly vesiculated scoriaceous particle with multiple, irregularly interconnected bubbles of different sizes. Particles shown in (d) and (f) were shaped mostly by vesiculation of fluid basaltic magma. \{continued) 
(g)

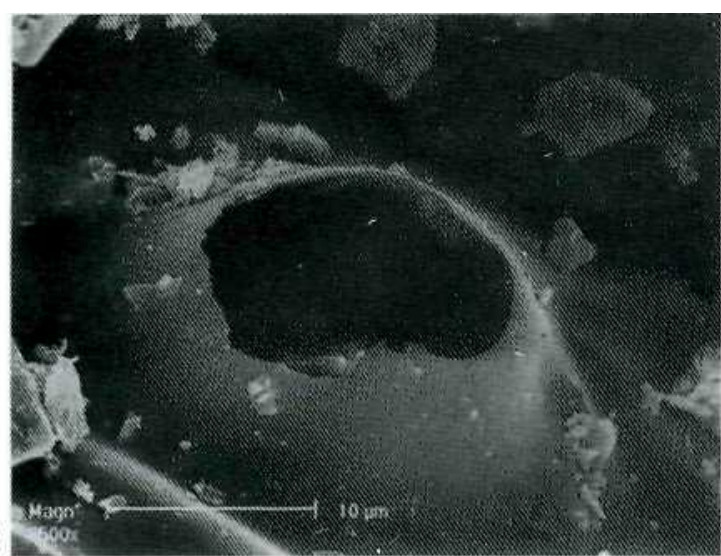

(i)

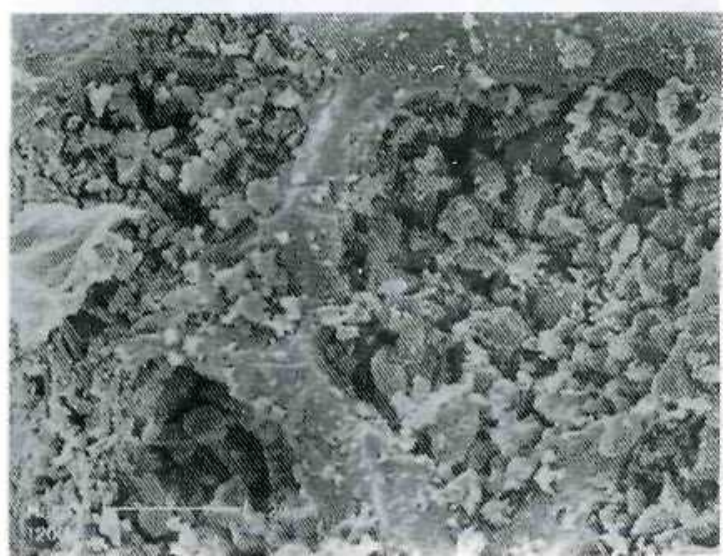

eruptions, in which fragmentation of liquid magma occurs as a result of a complex interplay between vesiculation and water-magma interaction (Heiken \& Wohletz, 1986). We use here the term water-magma interaction in a broad sense, as any process of magma fragmentation induced by its mixture with water, including the mechanism proposed by Kokelaar (1983). The resulting morphology of some particles was overprinted by subsequent rounding during recycling in the crater (Houghton \& Smith, 1993).

\section{EFFECTS AND DEPOSITS OF TSUNAMIS AND LAHARS}

\section{Tsunamis}

An area affected by tsunamis is marked around the lake by strong erosion of the shore, water-damaged bushes and distinctive deposits. The degree of shore

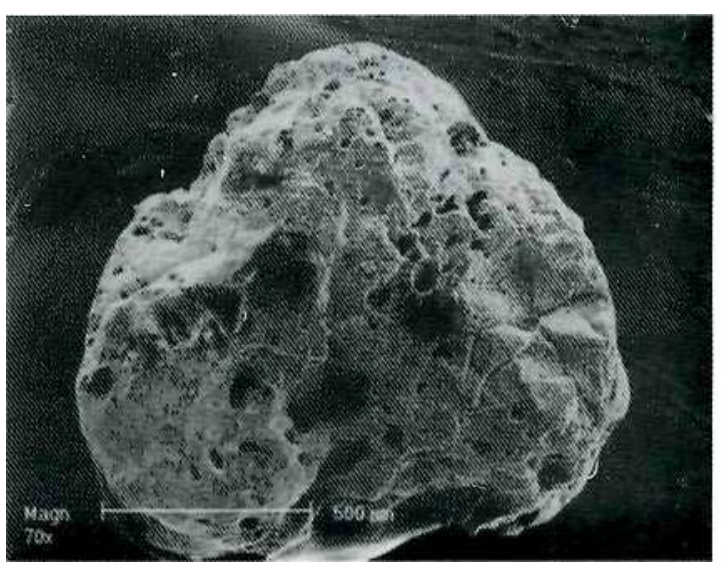

(h)

Fig. 12. (continued) (g) Small-scale feature of interbubble wall of particle illustrated in (f) shows plastic behaviour of material of the wall when gas bursts from one bubble to another, (h) Poorly vesiculated particle, subrounded by multiple recycling in the crater, (i) Vesicles clogged by fines, a characteristic feature of deposits of the second $4800^{14} \mathrm{C}$ yr BP eruption in the lake.

erosion declines with distance from the tuff ring, with the strongest erosion on the steep northern shore of the lake adjacent to the tuff ring. The slope was eroded up to $30 \mathrm{~m}$ above the level of the lake, with all plants and soil as much as $1.5 \mathrm{~m}$ thick stripped so as to expose poorly consolidated bedrock (Fig. 4a). No deposits of the eruption were found in the eroded area, other than numerous ballistic blocks pressed deeply into the slope. We infer that the shore here was eroded by both tsunamis and water-rich base surges moving outward from the crater. The tuff ring deposits adjacent to the base of the eroded slope are interbedded with layers, $10-20 \mathrm{~cm}$ thick, that are rich in clasts of yellow, altered rock, and pieces of plants eroded from the slope. Such layers are interpreted as backwash deposits of the tsunamis (Nishimura \& Miyaji, 1995) and/or of water pyroclastic flows formed from water-rich base surges.

Along the rest of the shoreline the action of the multiple tsunamis in many places formed new beaches 

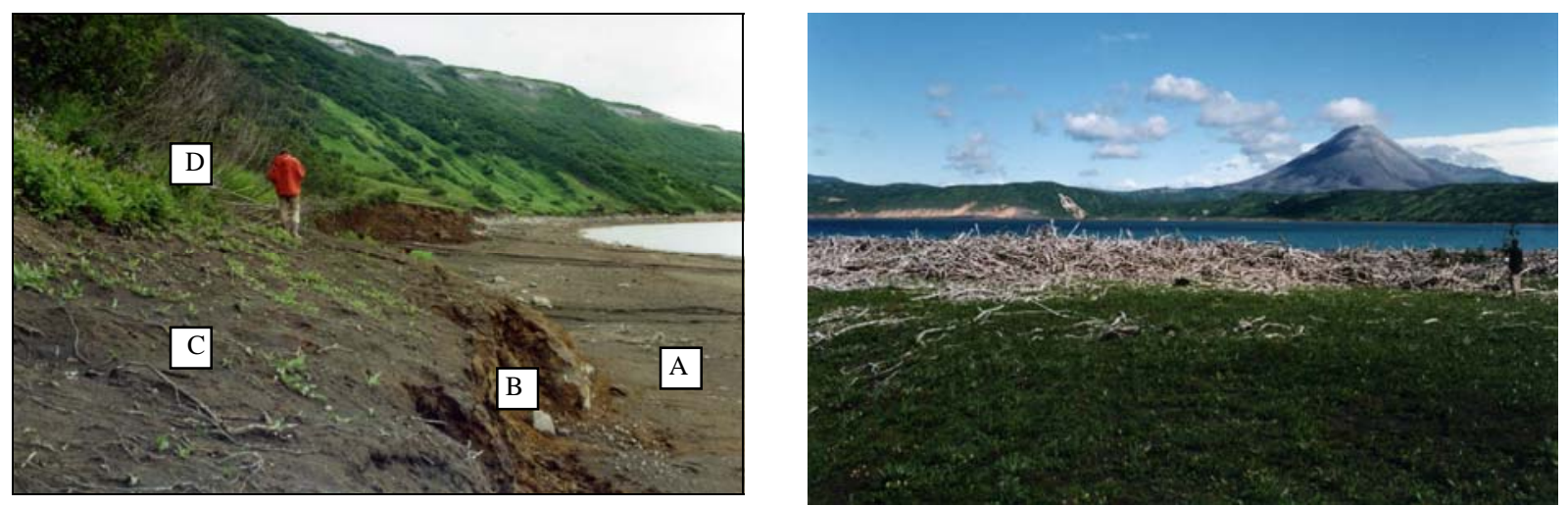

(a)

Fig. 13. (a) Shore of the lake affected by the 1996 tsunamis. Site with runup $5.8 \mathrm{~m}$ in Fig. 14a. The beach (A), cliff (B) and area with stripped vegetation (C) were formed by tsunami erosion. Limit of the tsunami invasion marked by dry bushes (D). (See text for details.) (b) Rampart formed by bushes cast ashore by tsunamis in the Karymskoye lake during the 1996 eruption. South-east shore of the lake; site with runup $3.8 \mathrm{~m}$ in Fig. 14a. Separate branches in the foreground mark the limit of tsunami inundation. Cone of Karymsky stratovolcano is visible in the background.

up to $50 \mathrm{~m}$ wide (area A in Fig. 13a), which are terminated by new cliffs up to 2-3 m high (area B). Further from the lake (inland, behind the cliff) is an area $\mathrm{C}$, up to $50 \mathrm{~m}$ wide, where the upper layer of soil up to $1.5 \mathrm{~m}$ thick was eroded and all plants were washed back into the lake. Along the outer boundary of the area inundated by the tsunamis (area D), soil was not eroded and bushes with some broken branches remained standing, but dead. It is inferred that these were killed by the warm, acidic lake water. Later they dried and serve as good markers of the inundation limit. The width of area D ranges from $1 \mathrm{~m}$ to $100 \mathrm{~m}$. The character of the damage to the bushes in area D differs from that caused by the base surges; they are not debarked on the side facing the crater.

Deposits left by the tsunamis can be divided into two main classes: those composed of non-floating material, which was deposited near the place where it was mobilized, and those representing floating objects, which before final deposition could drift considerable distances. Two types of deposits of the first class were discovered: individual blocks of poorly consolidated old tuff, and patches of sand. The blocks, 0.1-4 m across, originate from newly eroded cliffs. They are abundant on the north-east shore of the lake, and are almost entirely absent on the southern shore, which is composed mostly of hard, unerodible rocks. Blocks are scattered on the surface of the beaches or incorporated into the beach deposits below the cliffs (area A). Some blocks with volumes up to $1.3 \mathrm{~m}^{3}$ were transported by waves from their source up to $60 \mathrm{~m}$ inland (into areas $\mathrm{C}$ and $\mathrm{D}$ ). Patches of sand arc common in area
$\mathrm{D}$, and occur locally in area C. The patches are usually metres to tens of metres across and up to $35 \mathrm{~cm}$ thick. The sand, with scattered pebbles, fragments of plants and clots of soil, is well sorted (Table 1). Sometimes up to four parallel layers, with thickness $2-6 \mathrm{~cm}$, can be distinguished, and are inferred to reflect the multiple waves of tsunami runup and backwash. The composition and grain size of the deposit reflects the material mobilized by the tsunami. In the zone near the crater the deposit comprises mostly fresh basaltic pyroclasts from the tuff ring. Further from the crater the deposit is composed of sand from pre-eruption beaches.

Deposits of floated material are represented in areas $\mathrm{C}$ and $\mathrm{D}$ by scattered well-rounded pebbles of pumice, 2-10 $\mathrm{cm}$ in diameter, and branches of bushes, which are orientated mostly perpendicular to the direction of tsunami runup. Deposits are most abundant on the south-east shore, because of the north-west wind that blew during the eruption. Here pumice pebbles form patches and bands up to $3 \mathrm{~m}$ across and up to $20 \mathrm{~cm}$ thick, with openwork fabric. These resemble deposits of the much larger-scale tsunamis that accompanied the 1883 Krakatau eruption (Carey el al., 1996). In contrast to that eruption, pumice deposited by the 1996 tsunamis was not fresh, but was eroded by the tsunamis from old pyroclastic deposits. In both cases the floating pumice formed "pumice rafts', which were cast ashore. In Karymskoye lake the rafts also contained abundant floating bushes. After deposition on the south-east shore, interlaced branches of bushes formed 'wooden ramparts' up to $2 \mathrm{~m}$ high, 10-15 m wide and several hundred metres long (Fig. 13b). 
(a)

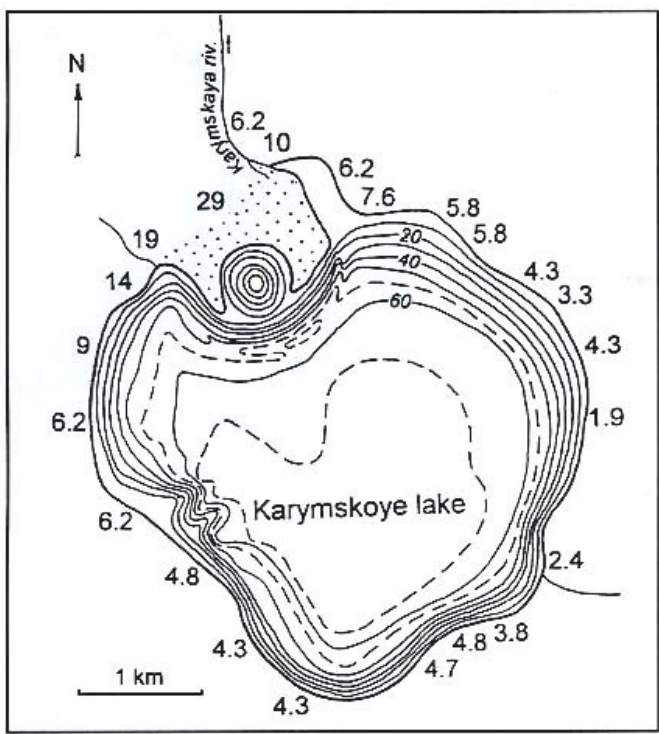

Branches of the ramparts are completely debarked with rounded or splintered, brush-like ends, which is inferred to indicate their prolonged beating by tsunami waves before final deposition.

There are two lines of evidence suggesting that the largest of the tsunamis occurred at the end of the eruption. First, the areas eroded by tsunamis are not covered by fall deposits of the eruption. Second, the composition of floated material deposited on the south-eastern shore shows that it originated mostly from the northern shore. Given the size of the lake, several hours during the eruption were needed for the floating material washed off the northern shore to drift across the lake to be deposited on the southeastern shore.

The distinctive band of devastation, and the tsunami deposits, allowed us to measure the runup height of the tsunamis at 24 points around the lake (Fig. 14). Because there were several tsunamis, the measurements represent the runup of the strongest event(s). The highest runup (20-30 m) occurs on the shore immediately adjacent to the tuff ring, $700 \mathrm{~m}$ from the centre of the crater. For the proximal zone, to radial distances $(r)$ up to $1.3 \mathrm{~km}$, the runup height $(R)$ shows rapid attenuation with distance as $\log R=-1.98 \log r+16.3$.

For the distal zone, $r>1.3 \mathrm{~km}, R$ decays more slowly as $\log R=-0.56 \log r+5.8$.

For the most distant points, runup was 2-3 $\mathrm{m}$.

'Tsunami' is a Japanese term that usually describes extraordinary water waves generated in seas or large

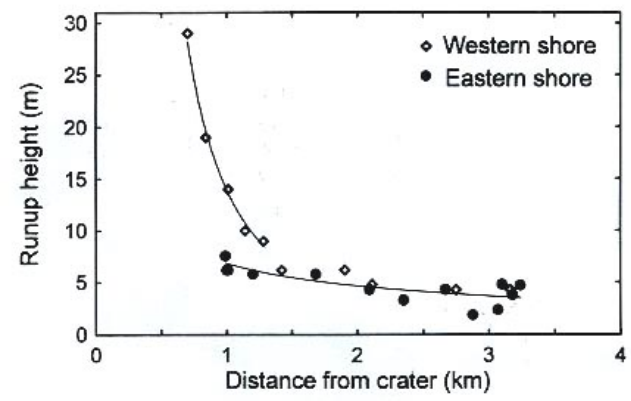

(b)

Fig. 14. (a) Heights of tsunami runup (in metres) around Karymskoye lake and bathymetry contours (in metres) after the eruption, (b) Tsunami runup versus distance from the crater. (Note change in trend $\sim 1.3 \mathrm{~km}$ from the crater.)

lakes by earthquakes, volcanic eruptions, landslides and so on (Latter, 1981). The fast decay of the runup of Karymskoye's tsunamis in the proximal zone is inferred to indicate that they were not only water waves, but also flows of water and/or water-pyroclastic mixtures. In the distal zone, however, evidence indicates that they were conventional tsunami waves (Belousov et al., 2000).

\section{Lahars}

Lahars left a broad fan of deposits where the Karymskaya river emerges from its first deep canyon in the caldera rim (Fig. 1b). The fan is $0.5 \mathrm{~km}$ long, $0.25 \mathrm{~km}^{2}$ in area, and 2-3 $\mathrm{m}$ in maximum thickness. It thins over a short distance and has a volume of $2.5 \mathrm{x}$ $10^{5} \mathrm{~m}^{3}$. The fan covered a marsh, and although most of bushes of the marsh were carried away or buried by lahars, some bushes remained standing along the outer boundary of the fan. Most bushes affected by lahars were killed, probably by acidic water. The stratigraphy of the fan was studied near its outer limit, where the deposit is thin and fine grained. The section consists of pre-eruption peat covered by two dark grey sandy layers, each $\sim 50 \mathrm{~cm}$ thick and capped by a fine grained light grey muddy horizon, $5 \mathrm{~cm}$ thick. The sandy layers are well sorted (Table 1), and have parallel or low-angle lamination defined by alternating relatively coarseand fine-grained discontinuous laminae a few millimetres thick. The layers consist of 
redeposited products of the 1996 eruption with admixed yellow, altered pumice eroded from older pyroclastic deposits. Observations suggest that the sandy layers were deposited by the first (2 January) and second (15 May) lahars of the eruption. The muddy layers settled out from temporary lakes that formed with each lahar event. The grain size and bedding characteristic of the deposits shows that both lahars had relatively low concentrations of solid particles and were hyperconcentrated flood flows (Smith, 1986).

\section{SUCCESSION OF EVENTS AND INTERPRETATION OF THE 1996 ERUPTION PROCESSES}

\section{Ascent of magma}

The 1996 crater, the chain of subsidence pits and the system of fissures are all aligned along a north-northeast fault (Fig. 1); it is inferred that the feeder dyke of the 1996 eruption was intruded along the fault, as has occurred here during previous eruptions of basic magma (see below).

The strong earthquake that occurred at the beginning of the pre-eruption swarm on the southern end of the fault probably was of tectonic origin, but it opened a path for magma to travel from a deep basaltic chamber toward the ground surface under the lake. There is petrological evidence that part of the basaltic magma from the dyke also intruded into the silicic magma chamber of the Karymsky stratovolcano and thus provoked its eruption (Eichelberger \& Izbekov, 2000).

\section{Vent-clearing explosion(s)}

The pre-eruption seismic swarm was associated with intrusion of a basaltic dyke $\sim 2.5 \mathrm{~m}$ wide along the fault zone, which is marked by hydrothermally altered breccia. A wave of elevated pore pressure propagated through the country rock ahead of the intruding dyke (Delaney, 1982; Elsworth \& Voight, 1992).

As the dyke approached the ground surface, opening of an eruption fissure initially allowed rapid decompression of the country rocks in which pore pressure was elevated. Decompression-fragmentation of the country rock along the fissure may have occurred by mechanisms analogous to those proposed for fragmentation of viscous magma under rapid decompression (Alidibirov \& Dingwell, 2000). The resulting fragments were transported upward by a gas stream emanating from the fissure, which probably originated from both boiling of decompressed hydrothermal fluids (circulating in the fault and heated by dyke intrusion) and upward migration of magmatic volatiles from the degassing, ascending dyke. The combination of the above events led to the first phreatic, vent-clearing explosion(s) of the eruption; no fresh magma was involved. Fragments of country rock probably were carried out from relatively deep levels of the fissure, having been accelerated to high velocities: the largest fragments were ejected the greatest distances (e.g. Self et al., 1980).

The phreatic explosion penetrated $\sim 50 \mathrm{~m}$ of water and a $1-\mathrm{m}$-thick ice sheet on the surface of the lake. Some of the ice blocks were incorporated, and together with ejected blocks of country rock left the largest impact craters. There is no evidence that this powerful explosion generated strong water waves; the ice sheet probably prevented a tsunami. The removal of rock fragments by this explosion widened the fissure, making a channel through which the following eruption occurred.

\section{Main stage of the eruption: Surtseyan activity}

The eruption of basic magma apparently started soon after the first vent-clearing explosion(s). The character of the basaltic eruption was directly linked to the fact that the gas-charged magma, with an average discharge $\sim 10^{6} \mathrm{~kg} \mathrm{~s}^{-1}$, had found its way to the ground surface under Karymskoye lake. The main part of the 1996 eruption consisted of a series of $\sim 100-200$ Surtseyan explosions with an average interval of $\sim 6$ min. Although the magnitude of the explosions varied, they probably each resulted from the same processes, and we will consider here a model for only one explosion 'cycle', or burst.

\section{Fragmentation of basaltic magma}

Between explosions, the crater of the tuff ring was filled with water, and the conduit throat was clogged by a mixture of water and pyroclasts left from the previous explosion burst. Magma lay deeper in the conduit, where there were no significant water-melt interactions; if such interactions had occurred, fragments of country rocks would be abundant in the deposit (Fisher \& Schmincke, 1984), which is not the case.

As indicated by the surface morphology and vesicularity indices of pyroclasts from the eruption, the explosions were caused both by vesiculation of magma and by energetic water-magma interaction 
(Heiken \& Wohletz, 1986; Houghton \& Wilson, 1989; Zimanowski, 1998). During each explosion, the process of magma fragmentation occurred in two stages. The first was mostly magmatic: rapid growth and ascent of bubbles pushed out a portion of vesiculated and partially fragmented magma from the upper part of the vent; this resembles the early stage of a Strombolian outburst. The second stage was mostly hydrovolcanic. It occurred when the products of the first stage were injected into the water-pyroclastic mixture filling the vent and crater. Contact with water led to additional fragmentation of magma. As a result, the shape of the pyroclastic particles displays features of magmatic fragmentation overprinted by features of hydrovolcanic fragmentation.

\section{Ejection and deposition}

At the start of an eruption burst, a gas-pyroclast mixture expanded explosively from the vent, pushing out and bulging upward the water and water-pyroclastic slurry clogging the crater. The height of a typical bulge reached several hundred metres above the lake surface. After several seconds fingers of the gas-pyroclast mixture penetrated the upper part of the bulge and entered the atmosphere as a cock's tail jet. Ejection of pyroclasts through the layer of water led to intermixing of jets with the water layer, forming an explosion fountain that was relatively cool, had a high content of water and steam, and was too heavy to rise buoyantly and form a sustained eruptive plume. Thus it began to descend towards the lake surface as an overloaded vertical eruption column collapsing under gravity (e.g. Wilson el al., 1980). The descending mixture formed a very wet base surge in which droplets of water, as well as pyroclasts, were a major component. We here term the flowing mixture a base surge, but add the modifier 'water-rich' to distinguish it from more dry, conventional, gas pyroclast base surges. Water-rich base surge can be considered to be the end member of wet base surges.

While the surge propagated radially from the crater, it became density stratified as a result of gravitational settling of pyroclasts and droplets of water (Valentine, 1987). We suggest that this process led to formation of a distinct underflow at the base of the surge. In this underflow water was the continuous phase in which pyroclastic particles and gas bubbles were suspended. Thus, the upper gas-pyrodaslic surge was a transport system, which contributed material to the lower waterpyroclast underflow, which was the depositional system (Fisher, 1990). Deposition from the underflow was similar to deposition from hyperconcentrated flood flow (Smith, 1986).

Both surges and underflows moved subaerially along the surface of the tuff ring; where the surges began to climb the caldera wall, the water-pyroclastic underflow decelerated first and began to flow back downslope (topographic blocking of Fisher, 1990), eroding the sleep slope of the caldcra and depositing backwash material near the base of the wall. As a result of topographic blocking, the densest and wettest lower part of the surge was separated from the upper, relatively dry part of the base surge, which propagated further, leaving distal base-surge deposits similar to those formed by deposition from relatively low-energy surges (Beiousov el al., 1998). The surge propagated until it lost most of its pyroclastic load, became lighter than the surrounding air, and lifted buoyantly.

The above situation occurred only near the end of the eruption, when the upper part of the tuff ring had emerged from the lake. Before emergence of the ring, collapse of the eruptive column created surges that moved along the water surface. The behaviour of the water-pyroclast underflow in this situation is unclear. The density of the surge underflow is expected to have been higher than that of water, so it probably sank and then propagated subaqueously along the surface of the tuff ring as a sediment gravity flow (White, 1996).

After each explosion, a part of the pyroclastic material fell back into the crater and was temporarily stored there until the nest explosion remobilized it. Some part of the material may have experienced several expulsions and collapses before its final ejection from the crater (Houghton \& Smith, 1993). Such recycling resulted in rounding of pyroclasts. Additional rounding may have occurred during transportation of clasts by turbulent surges.

\section{End of the eruption}

Near the end of the eruption we infer that the magma ascent rate declined and the feeder dyke began to freeze. The walls of the dyke were covered by a thick layer of partially solidified melt, and a waning stream of fresh magma detached clots of this semi-solid material (sometimes enclosing fragments of country rock) and transported it upward. Most of the erupting magma near the end of the eruption may have represented such clots covered by only a thin layer of freshly arrived melt. The final explosions of the eruption ejected more and more of these clots, which led to an abrupt increase in the abundance of coarse-grained material in the uppermost layers of the tuff ring, and 
to the deposition of scoria-crust bombs. The basaltic bombs decrease in size and abundance with distance from the crater and their source during the final explosions was probably shallow (e.g. Self et al., 1980). The appearance of abundant scoria-crust bombs in the course of an eruption may serve as an indicator that the feeder dyke is freezing and the eruption's end is approaching.

The largest of the tsunamis occurred at the end of the eruption. This may indicate that the explosions that look place near the end of the eruption were stronger than those of the main stage. Alternatively, these explosions, which ejected only bomb-sized clasts from shallow depths, more effectively pumped energy into the generation of water waves than did the previous explosions (which ejected a large amount of finer-grained material and were at somewhat greater depth). The waves redistributed coarse-grained material on the surface of the tuff ring to form large-scale ripples, and cast ashore rafts of floating pumice and bushes.

\section{DEPOSITS AND STYLES OF PREHISTORIC ERUPTIONS IN THE LAKE}

Our studies have shown that the 1996 eruption was the third episode of Holocene volcanic activity within the Akademiya Nauk caldera (Belousov el al., 1997). Basalt-basaltic andesite tephra of the two pre-1996 eruptions crops out along the coast of the lake, being thickest in its northern part (Fig. 15). The eruptions were closely spaced in time and occurred at c. $4800{ }^{\mathrm{II}} \mathrm{C} \mathrm{yr}$ BP.

\section{Deposit of the first eruption}

The deposit of the first eruption is in general similar to the deposit of the 1996 tuff ring. The exposed thickness of the deposit is up to $10 \mathrm{~m}$, and the deposit is composed of monotonous, rhythmically intercalated parallel, normally graded, grain-supported, dark grey beds of moderately sorted ash lapilli (Figs 8, 9, 15 \& 16; Table 1). Inclination of the beds is very gentle; in outcrop they appear horizontal. The coarsest, lower part of each 0.3-1-m-thick bed commonly has an openwork fabric. The beds are well defined and laterally continuous; no erosional discordances have been found. Contacts between the beds commonly arc diffuse. In some places, the unit is completely structureless, and may represent syneruptive slump deposits.

Grain-size distributions of samples from the deposit are commonly unimodal ( -4 phi to -2 phi), with a very low-content of fines (Figs 9b \& 15; Table 1). In the sections studied the deposit is notably coarser than the 1996 tuff ring deposit. Juvenile basaltic clasts constitute $>95 \%$ of the deposit. They have vesicularity indices of 9-49\% (mean 28\%) (Fig. 11), and are less vesicular than the 1996 juvenile clasts. Coarse lapilli are mostly irregular in shape and angular to subrounded. The surface morphology of sand-sized clasts from the deposit is identical to that of the 1996 deposits, and is inferred to reflect a similar phreatomagmatic character of the older eruption.

Most of the studied sections arc inferred to have been deposited subaqueously. Evidence is provided by a 10-20-cm-thick layer of yellowish fine ash (Md $7.2 \mathrm{phi}$; sorting 1.3phi), which covers the deposit (Fig. 16b). The
Fig. 15. Thickness (in metres) of pyroclastic deposits of the first (I) and second (II) eruptions that occurred in Karymskoye lake at $4800{ }^{14} \mathrm{C}$ yr BP, with grain-size histograms for representative samples. Numbers on the sketch map show thickness of second eruption/thickness of first eruption. Filled circle indicates site of section 6 , where samples represented by the histograms were collected.
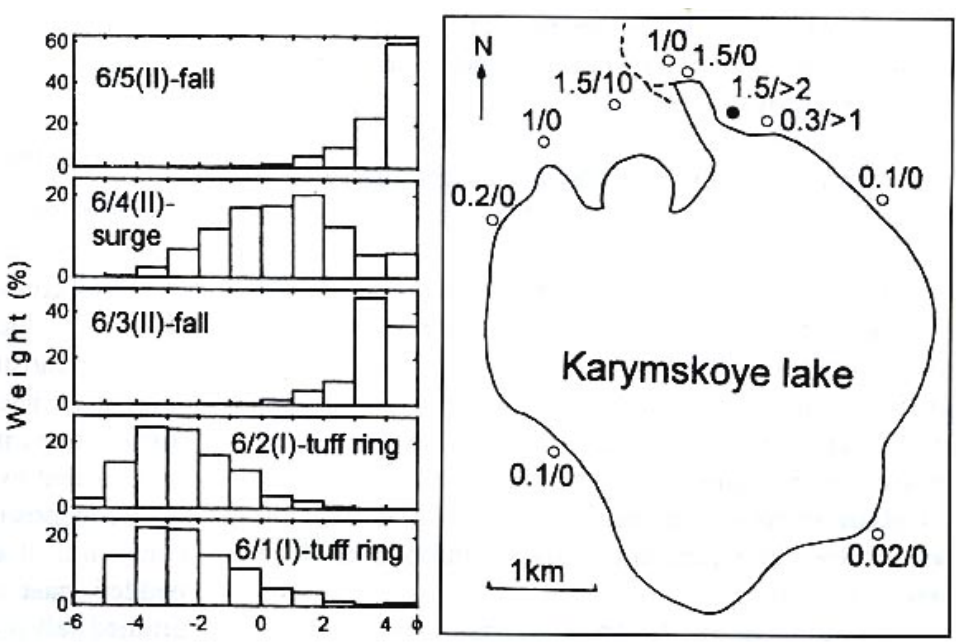
(a)
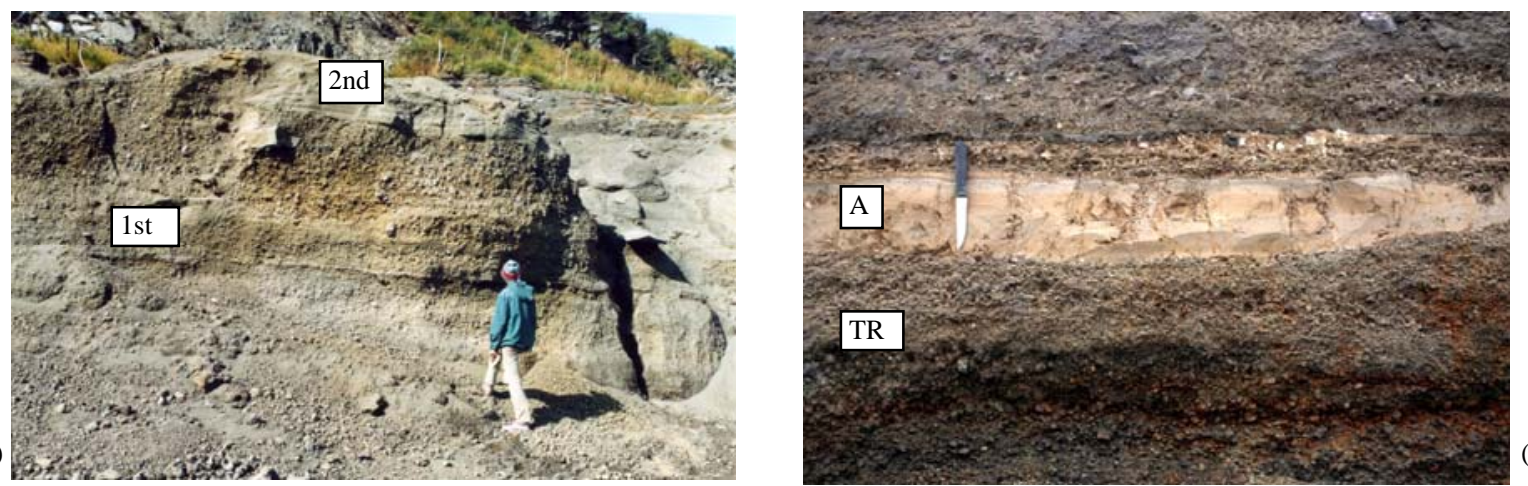

(b)

(c)

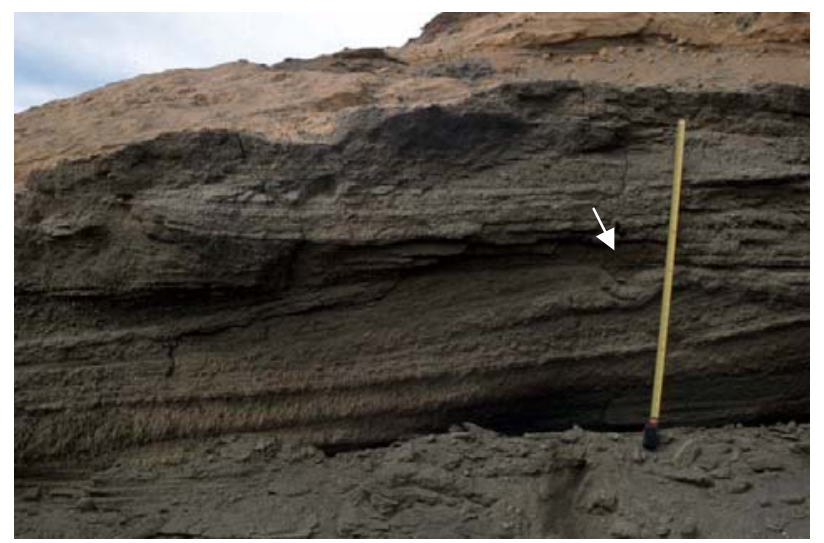

Fig. 16. Deposits of the first and second $4800{ }^{14} \mathrm{C}$ yr BP eruptions in the lake, (a) Thick coarse-bedded lapilli of the first eruption tuff ring, covered above erosional contact by cross-stratified surge beds of the second eruption. Large angular clast near the contact is accidental fragment of lava. Thin, fine-grained layer in the deposit of the first eruption (at the level of person's head) divides better-sorted, subaqueously deposited lower pan of the deposit from more poorly sorted, subaerially deposited upper part. Site 1.5/10 in Fig. 15 . (b) Two uppermost, normal-graded lapilli layers of the tuff ring deposit of the first eruption (TR) covered by layer of fine ash (A) settled from lake water after the eruption. Site 1.5/2 in Fig.15. Scale is $35 \mathrm{~cm}$ long. (c) Intercalation of cross-bedded base-surge deposits and fine-grained fall layers of second eruption. Site 1.5/10 in Fig.15. (Note a small bomb sag in the centre of the picture (arrow).) The surges probably moved from left to right. Shovel is $\sim 1.5 \mathrm{~m}$ long.

fine ash, which sometimes has ripple marks, is inferred to have been separated from the coarse fraction during deposition in water. After the eruption it settled on the bottom of the lake, just as occurred in 1996. The position of the fine ash layer shows that the level of the lake $4800{ }^{14} \mathrm{C}$ yr ago was at least $5 \mathrm{~m}$ higher than the present level.

The 1996 tuff ring buried the broad shoal in the northern part of the lake: the shoal represents an older tuff ring 15-20 m high with a crater $1350 \mathrm{~m}$ in diameter (Belousov et al., 1997; Ushakov\& Fazlullin, 1998). The rim of this crater is still expressed on the bottom of the lake as an underwater bar at a depth of $50 \mathrm{~m}$ surrounding the 1996 crater (Fig. lb). We assign this old edifice to the first eruption in the lake, $4800{ }^{14} \mathrm{C}$ yr BP.

The similarity of the $4800{ }^{\mathrm{I}} \mathrm{C}$ yr BP and 1996 tuff ring deposits indicates similar eruption styles and depositional processes.

\section{Deposits of the second eruption}

The deposits of the second eruption either directly overlie the deposit of the first eruption above an erosional contact, or are separated from it by deposits, up to $2 \mathrm{~m}$ thick, of ephemeral streams, which accumulated during a short period between eruptions (Fig. 16a). The deposit of the second eruption did not form a new, individual edifice, but covered the tuff ring formed by the first eruption.

The deposit is a 2-m-thick lapilli ash succession consisting of dark grey to greenish layers of cross-bedded base-surge deposits intercalated with fine grained fall layers up to $20 \mathrm{~cm}$ thick (Figs 8, 9, 15 
\&16c). There are rare clasts of basaltic andesite up to $10 \mathrm{~cm}$ with impact-sag structures (Fig. 16c) that were deposited ballistically on the wet, cohesive surface of fall and base-surge deposits.

The surge deposits have well-developed duneforms, with an amplitude of 10-40 $\mathrm{cm}$ and a wavelength of 1-5 $\mathrm{m}$. The stoss side has an inclination of $10-20^{\circ}$; the lee side is always more gentle, dipping $0-12^{\circ}$. Evidence for stoss-side deposition and lee-side erosion, indicating upstream migration of dune crests, is common. In several outcrops the deposit is massive, possibly as a result of syneruptive slumping. Both the surges and intercalated fall layers have numerous rim-type accretionary lapilli up to $1.5 \mathrm{~cm}$ across (Schumacher \& Schmincke, 1991). The surges commonly contain armoured lapilli (Fisher \& Schmincke, 1984).

The surge deposits are moderately to poorly sorted (Fig, 8). The deposits commonly have unimodal grain-size distributions, and are notably fines-poor relative to the deposits of 1996 distal base surges (Figs 9b \& 15; Table 1). Fall deposits are very fine grained and well sorted (Figs $8 \& 9$; Table 1).

In contrast to the deposits of the first $\left(4800{ }^{14} \mathrm{C}\right.$ yr BP $)$ and third (1996) eruptions, clasts of the second (4800 ${ }^{14} \mathrm{C}$ yr BP) eruption are covered by a thin layer of fine ash (light mud coating of Houghton \& Smith, 1993). This makes it difficult to estimate a percentage of true juvenile clasts in the deposit, but locally it is clear that some layers of the surge deposits are strongly enriched in coarse-grained accidental clasts from underlying strata. Such layers probably mark episodes of intensive widening of the vent, possibly as a result of energetic water-magma interaction in the conduit. Juvenile clasts have vesicularity indices of $18-65 \%$ (mean 52\%) - significantly larger than the vesicularity of juvenile clasts from the first and 1996 eruptions (Fig. 11). Coarse lapilli are irregular in shape and mostly angular. The morphology of the sand-sized particles that constitute the deposit is similar to that of the 1996 deposit, but there is more abundant adhering dust, which commonly completely clogs vesicles (Fig. 12i).

The end of the eruption is marked by a 1-m-thick layer of large, thoroughly vesiculated, scoriaceous bombs overlying the sequence of surge and fall deposits. Deposits of water-rich base surges like those that formed the tuff rings of the first and 1996 eruptions were not found.

The character of the deposit of the second eruption is very different from that of the first and of the third (1996) eruptions. The well-developed, cross-bedded base-surge deposits of the second eruption resemble base-surge deposits of the 1965 Taal eruption, in which volcanic explosions occurred in very shallow water (Moore et al., 1966; Moore, 1967; Waters \& Fisher, 1971). Thus, we infer that the vent of the second eruption was situated in very shallow water or even onshore, penetrating water-saturated products of the first eruption. In this situation there was neither a significant layer of water above the vent, nor an abundance of water during water-melt interaction, as took place during the first eruption and in 1996. The reduced interaction with water led to more violent explosions that produced a large amount of finegrained particles. During propagation of the surges of the second eruption much of their fine fraction was elutriated into overriding convective clouds, from which were deposited most of the fall deposits of the eruption, which are much finer grained than fallout of the 1996 eruption. Hence we infer that the surges of the second eruption were more inflated and drier than surges of the 1996 eruption.

Base surges of the second eruption were also much more energetic than surges of 1996 eruption; they were able to travel $>4 \mathrm{~km}$ and lo affect the whole lake. In contrast to the 1996 surges, particles from the surges of the second eruption came to rest after protracted basal traction, which led to formation of excellent cross-bedding. Scoriaceous bombs ejected at the end of the second eruption probably marked its transition from a phreatomagmatic eruption to a purely magmatic one.

\section{CONCLUSIONS}

The eruptions in Karymskoye lake show the influence that a shallow layer of water above a vent can have on the style of basaltic eruptions. If the 1996 eruption had occurred in a dry environment the inferred discharge rate suggests that it probably would have been a vigorous Strombolian or even sub-Plinian eruption, resembling that of Mihara Yama in Japan on 21-22 November 1986 (Earthquake Research Institute, Tokyo, 1988). Instead, several tens of metres of standing water above the vent drastically changed the character of the 1996 eruption. Rather than forming a sustained eruptive plume, unstable eruptive columns with a high water and steam content immediately collapsed back into the lake. In this situation $>95 \%$ of all pyroclastic products of the eruption were deposited from a specific type of base-surge that spread radially from the crater. To indicate their inferred origin from the collapse of very wet Surtseyan slugs, we term 
them water-rich base surges. A water-rich base surge can be considered to be the end member of wet base surges.

Gravitational settling of pyroclasts and droplets of water in a water-rich surge forms a water-pyroclast underflow at its base, which serves as the depositional system for the surge (Fisher, 1990). Deposition from the underflow is akin to deposition from hyperconcentrated flood flow (Smith, 1986). The deposits of water-rich surges have an extremely low content of fines, and have none of the wave laminations that are characteristic of many base-surge deposits. Instead, they form well-graded parallel layers. The type of grading probably depends on the concentration of pyroclaslic particles in each particular underflow of the water-rich base surges.

As a result of elevation of ambient pressure (50 m of water depth above the vent) and rapid chilling in the water, pyroclastic particles of the eruption are notably denser than regular basaltic scoria. The inferred abundance of water during the water-magma interaction is probably the reason why the resulting deposits are not as fine grained as the deposits of the subaerial phreatomagmatic eruptions. An unusual feature of the lapilli-sized clasts of the eruption is their significant rounding, uncommon for most types of primary pyroclastic deposits. Apparently, a layer of water above the vent prevented many pyroclasts from being ejected from the crater by the explosion in which they formed. Instead, they experienced several episodes of recycling in the crater before final ejection, which produced their unusual roundness. The presence of several tens of metres of standing water above the vent also strongly influenced the hazards associated with the eruption. At distances exceeding $1.3 \mathrm{~km}$ from the vent, only tsunamis and lake-outflow lahars were dangerous. Closer to the crater base surges and ballistic material were very destructive.

The first of the $4800{ }^{14} \mathrm{C}$ yr BP eruptions in the lake was very similar to the 1996 eruption, probably because of similar water depths above the vent. The second of the $4800{ }^{\mathrm{I}} \mathrm{C}$ yr BP eruptions probably occurred in very shallow water; its deposits resemble those of subaerial phreatomagmatic eruptions. Absence either of abundant water during water-melt interaction or of high ambient pressures resulted in violent explosions that produced a large amount of fine-grained particles. Water-rich base surges were not generated. Instead, gas-pyroclastic base surges (much more energetic and dry than surges of the 1996 eruption) and related ash clouds transported most of the material of the second eruption and were the main sources of hazard associated with the eruption.
Although the studied eruptions occurred in a lake, most of the results obtained are also applicable to shallow submarine eruptions of basic magma.

\section{ACKNOWLEDGEMENTS}

The idea of this publication was strongly supported by James White. We are very grateful to Yaroslav Muravyev, Sergei Fazlullin, Alexei Ozerov, Sergei Ushakov, Elena Grib, and Evgenii Gordeev, who participated with us in the field at Karymskoye lake and in very helpful discussions. We acknowledge Vilorii Bakhtiarov, who kindly provided us with a videotape of the eruption. Scanning electron microscope analysis of pyroclasts and preparation of the manuscript were carried out during our postdoctoral fellowship at Pennsylvania State University, supported by an NSF grant to Barry Voight. The English text of the paper was improved by Amanda Clarke and Barry Voight. Careful critical reviews by James White, Bruce Houghton and an anonymous reviewer have helped this paper considerably. The research described in this publication was made possible in part by Alexander von Humboldt Foundation and by Grant RG1-172 from the Civilian Research and Development Foundation and the Russian Government.

\section{REFERENCES}

AlidiBIROV. M. \& DingweLL, D.B. (2000) Three fragmentation mechanisms for highly viscous magma under rapid decompression. J. Volcanol. geotherm. Res., 100, 413-423.

BANKS, N.G. \& HoBLITT. R.P. (1981) Summary of temperature studies of 1980 deposits. In: The 1980 Eruptions of Mount St Helens. Washington (Eds LIPMAN, P.V. \& Mullineaux. D.R.], US geol. Surv. Prof. Pap., Denver, CO, 250, 295-313.

BeLousov, A. (1996) Deposits of the 30 March 1956 directed blast at Bezymianny volcano. Kamchatka, Russia. Bull. Volcanol.,57,649-662.

Belousov, A.B., Belousova. M.G. \& Muravyev, Ya. D. (1997) Holocene eruptions in ihe Akademiya Nauk caldera and the age of the Karymsky stratovolcano, Kamchatka. Trans. Russ. Acad. Sci.. Earth Sci. Sect. 335, 653-657.

Belousov, A.. Belousova, M. \& Voight. B. (1998) Powerful pyroclastic surge at Bezymianny volcano on May 9-10, 1997 (Kamchatka, Russia). EOS Trans. Am. geophys. Union. 79,936-937.

Belousov, A., Voight, B., Belousova. M. \& Muravyev, Y. (2000) Tsunamis generated by subaquatic volcanic explosions: unique data from 1996 eruption in Karymskoye lake, Kamchatka. Russia. Pure appl. geophys., 157,1135-1143.

BRAITSEVA, O.A. \& MELEKESTSEV. I.V. (1990) Eruptive history of Karymsky volcano, Kamchatka, USSR, based on tephra stratigraphy and $\mathrm{C}^{14}$ dating. Bull. Volcanol, 53, 195-206. 
Carey, S., Sigurdsson, H., Mandeville, C. \& Bronto, S. (1996) Pyroclastic flows and surges over water: an example from the 1883 Krakatau eruption. Bull. Volcanol, 57, 493-511.

CAS, R.A.F., LANDIS, C.A. \& FORDYCE. R.E. (1989) A monogenetic. Surtla-type, Surtseyan volcano from the Eocene-Oligocene Waiareka- Deborah volcanics, Otago. New Zealand: a model. Bull. Volcanol.,51, 281-298.

DELANEY. P.T. (1982) Rapid intrusion of magma into wet rock: ground water flow due to pore pressure increases. J. geophys. Res.,87, 7739-7756.

EARTHQUAKE RESEARCH INSTITUTE. TOKYO (1988) The 1986-87 Eruption of Izu-Oshima Volcano. Earthquake Research Institute, Tokyo.

EICHELBERGER, J.C \& IZBEKOV, P.E. (2000) Eruption of andesite triggered by dyke injection: contrasting cases at Karymsky volcano. Kamchalka and Mt. Katmai, Alaska. Phil. Trans. Royal. Soc. London A, 358, 1465-1485.

ELSWORTH, D. \& VOIGHT, B. (1992) Theory of dike intrusion in a saturated porous solid. J. geophys. Res.. 97, 9105-9117.

FAZLULLIN, S.M., USHAKOV, S.V., SHUVAlOV, R.A., et al. (2000) The 1996 subaqueous eruption at Academii Nauk volcano (Kamchatka) and its effects on Karymsky lake. J. volcanol. geotherm. Res., 91. 181-193.

FEDOTOV, S.A. (Ed.) (1991) Active Volcanoes of Kamchatka. Nauka, Moscow.

FEDOTOV, S.A. (1998) Study and mechanism of the simultaneous 1996 Karymsky volcano and Akademii Nauk caldera eruptions in Kamchalka. Volcanol. Seismol., 19, 525-566.

FISHER. R.V. (1990) Transport and deposition of a pyroclastic surge across an area of high relief: the 18 May 1980 eruption of Mount St. Helens, Washington. Geol. Soc. Am. Bull, 102, 1038-1054.

FISHER. R.V. \& SCHMINCKE, H.U. (1984) Pyroclastic Rocks. Springer, Berlin.

Francis. P. (1993) Volcanoes: a Planetary Perspective. Clarendon Press, Oxford.

GRIB. E.N. (1998) Petrology of ejecta produced by the Akademiya Nauk caldera eruption of January 2-3, 1996. Volcanol. Seismol, 19, 605-635.

GUSHCHENKO, I.I. (1979) Eruptions of World Volcanoes (Catalogue). Nauka. Moscow (in Russian).

HEIKEN, G.H. (1971) Tuff rings: examples from the Fort Rock-Christmas Lake valley basin, south-central Oregon. J. geophys. Res , 76, 5615-5626.

HEIKEN. G.H. \& WOHLETZ, K.H. (1986) Volcanic Ash. University of California Press, Berkeley.

HOBLITT, R.P. \& HARMON, R.S. (1993) Bimodal density distribution of cryptodome dacite from the 1980 eruption of Mount St. Helens, Washington. Bull. Volcanol., 55, 421-437.

Houghton, B.F. \& SCHMincKe, H.-U. (1986) Mixed deposits of simultaneous strombolian and phreatomagmatic volcanism: Rothenberg volcano. East Eifel volcanic field. Volcanol. geothermal Res., 30, 117-130.

Houghton, B.F. \& SMITH, R.T. (1993) Recycling of magmatic clasts during explosive eruptions: estimating the true juvenile content of phreatomagmatic volcanic deposits. Bull. Volcanol., 55, 414-420.

Houghton, B.F. \& WiLson, C.J.N. (1989) A vesicularily index for pyroclastic deposits. Bull. Volcanol., 51, 451-462.

INMAN. D.L. (1952) Measures for describing the size distribution of sediments. J. sediment. Petrol.. 22, 125-145.
IVANOV, B.V. (1970) Eruption of the Karymsky Volcano in 1962-65 and the Karymsky Group Volcanoes. Nauka, Moscow (in Russian).

KOKELAAR, B.P. (1983) The mechanism of Surtseyan volcanism. J. geol. Soc. London, 140, 939-944.

LATTER, J.M. (1981) Tsunamis of volcanic origin: summary of causes, with particular reference to Krakotoa, 1883. Bull. Volcanol., 44, 467-490.

LEONOV, V.L. (1998) Ground surface breaks produced by an earthquake and volcanic eruptions in the Karymsky volcanic center on January 1 2, 1996. Volcanol. Seismol., 19, 655-674.

LORENZ. V. (1973) On the formation of maars. Bull. Volcanol., 37, 183-204.

LOWE, D.R. (1982) Sediment gravity flows: II. Depositional models with special reference to the deposits of high-densily turbidity currents. J. sediment. Petrol., 52, 279-297.

Machado, F., Parson, W.H., Richards. A.F. \& Mulford, J.F. (1962) Capelinhos eruption of Fayal volcano, Azores, 1957-58. J. geophys. Res., 67, 3519-3529.

Maguskin, M.A., Fedotov, S.A., Levin, V.E. \& BAKHTIAROV. V.F. (1998) Ground surface deformation caused by seismic and volcanic activity in the Karymsky volcanic center during January 1996. Volcanol. Seismol, 19, 637-654

MASURENKOV, YU. P. (Ed.) (1980) A Volcanic Center: Structure. Dynamics and Rock Compositions in the Karymsky Structure. Nauka, Moscow (in Russian).

MoORE. J.G. (1967) Base surges in recent volcanic eruptions. Bull. Volcanol. 30, 337-363.

MoOre. J.G., NAKAmura, K. \& AlCARAZ. A. (1966) The 1965 eruption of Taal volcano. Science. 151, 15 -20.

MURAVYEV, YA. D., FEDOTOV, S.A., BUDNIKOV, V.A.. el al. (1998) Volcanic activity in the Karymsky center in 1996: summit eruption at Karymsky and phreatomagmatic eruption in the Akademii Nauk caldera. Volcanol. Seismol, 19. 567-604.

NAIRN. I.A.. WoOD. C.P \& Hewson, C.A.Y. (1979) Phreatic explosions of Ruapehu; April 1975. N Z. J. Geol. Geophys.. 22. 155-173.

NishimURA, Y. \& MiYAJi. N. (1995) Tsunami deposits from the 1993 Southwest Hokkaido earthquake and the 1640 Hokkaido Komagatake eruption. Northern Japan. Pure appl. geophys.. 144. 719-733.

SCHUMACHER, R. \& SCHMINCKE. I l.-U. (1991) Internal structure and occurrence of accretionary lapilli-a case study at Laacher See Volcano. Bull. Volcanol., 53, 612-634.

SCHUMACHER. R. \& SCHMINCKE, H.-U. (1995) Models for the origin of accretionary lapilli. Bull. Volcanol., 56, 626-639.

Self, S., KienLE, J. \& Huot, J.-P. (1980) Ukinrek maars, Alaska. II. Deposits and formation of the 1977 craters. J. Volcanol. geothermal Res., 7, 39-65.

SHERIDAN. M.F. \& WOHLETZ. K-.H. (1983) Hydrovolcanism: basic considerations and review. J. Volcanol. geothermal Res., 17,1-29.

SMITH. G.A. (1986) Coarse-grained nonmarine volcaniclastic terminology and depositional process. Geol. Soc. Am. Bull. 7, 1-10.

SoHN, Y.K. \& CHOUGH. S.K. (1989) Depositional processes of the Suwolbong tuff ring, Cheju Island (Korea). Sedimentology 36, 837-855.

SoHN, Y.K. \& CHOUGH, S.K.. (1992) The Ilchulbong tuff cone, Cheju Island, South Korea: depositional processes 
and evolution of an emergent, Surtseyan-type tuff cone. Sedimentology, 39, 523-544.

THORARINSSON, S, (1964) Surtsey: the New Island in the North Altanlic. Almena Bokafelagid, Reykjavik.

THORARINSSON, S, EINARSSON, T., SIGVALDASON, G. \& ELISSON, G. (1964) The submarine eruption off the Vestmann Islands 1963-64. Bull. Volcanol., 27, 435-445.

UshaKov, S.V. \& FAzLULlin, S.M. (1998) Morphometric characteristics of lake Karymskoye after an underwater eruption. Volcanol. Seismol, 19, 675-683.

VALENTINE, G.A. (1987) Stratified flow in pyroclastic surges. Bull. Volcanol., 49.616-630.

WALKER, G.P.L. \& CROASDALE, R. (1972) Characteristics of some basaltic pyroclastics. Bull. Volcanol, 35, 303-317.

WATERS, A.C. \& FisheR, R.V. (1971) Base surges and their deposits: Capelinhos and Taal volcanoes. Geophys. Res., 76, 5596-5614.

WHITE. J.D.L. (1996) Pre-emergeal construction of a lacustrine basaltic volcano. Pabvant Butte, Utah (USA). Bull. Volcanol., 58, 249-262.

Wilson, L., SPARKS, R.S.J. \& WALKER, J.P.L. (1980)
Explosive volcanic eruptions, IV. The control of magma properties and conduit geometry on eruption column behaviour. Geophys. J. R. astron. soc, 63,117-148.

WOHLETZ, K.H. (1983) Mechanism of hydrovolcanic pyroclast formation: grain size, SE microscopy, experimental studies. J. Volcanol. geothermal Res., 17, 31-63.

WOHLETZ, K.H. (1986) Explosive magma-water interactions: thermodynamics, explosion mechanisms, and field studies. Bull. Volcanol., 48, 245-264.

WOHLETZ, K.H. \& MCQUeEN, R.G. (1984) Experimental studies of hydromagmatic volcanism. In: Explosive Volcanism: Inception, Evolution and Hazards Studies in Geophysics, pp. 158-169. National Academy Press, Washington, DC.

YAMAMOTO, T., SOYA. T , SUTO, S., et at. (1991) The 1989 submarine eruption off eastern Izu Peninsula, Japan: ejecta and eruption mechanisms. Bull Volcanol., 53, $301-$ 308.

ZimANOWSKI, B. (1998) Phreatomagmatic explosions. In: From Magma so Tephra (eds. A. Freundt \& M. Rosi) pp. 25-54. Elsevier, Amsterdam. 